\title{
58. GEOLOGIC HISTORY OF GOBAN SPUR, NORTHWEST EUROPE CONTINENTAL MARGIN ${ }^{1}$
}

\author{
Pierre Charles de Graciansky, École Nationale Supérieure des Mines, Paris \\ and \\ C. Wylie Poag, U.S. Geological Survey, Woods Hole ${ }^{2}$
}

\begin{abstract}
Drilling on Leg 80 of the Deep Sea Drilling Project-International Phase of Ocean Drilling was conducted on a transect of four sites (548-551) across the continent-ocean boundary at Goban Spur, a prominent southwest-trending structural and topographic high on the Irish continental slope. Drilling results have been integrated with physiographic, gravimetric, paleomagnetic, and seismostratigraphic data to provide a comprehensive interpretation of the geologic history of this sediment-starved passive margin.

The geologic history of Goban Spur and adjacent regions may be divided into three periods: (1) a pre-rift period, beginning at the end of the Hercynian orogeny, was marked by several phases of regional faulting. From the late Paleozoic to the Triassic, a major phase was responsible for the development of northeast-trending grabens and horsts, which were especially active areas of deposition during the early and middle Mesozoic. A second phase created northwesttrending listric, normal fault systems which delineated the pre-Atlantic rift system of the Early Cretaceous. (2) A terminal period of active rifting began approximately at the Jurassic/Cretaceous boundary (late Cimmerian phase), and was marked by a regional emergence. Syn-rift deposition is recorded at Goban Spur by accumulation of a transgressive sequence of hyposaline to pelagic sediments, chiefly Barremian. Interpretation of seismic profiles indicates that (?)Aptian sequences also were deposited in the deeper half-grabens during this phase of rifting. Volcanic rocks appear to be rare or absent in the syn-rift deposits on Goban Spur. (3) The post-rifting period began when ocean crust was accreted in a trough approximately $2000 \mathrm{~m}$ deep, beneath what is now the Porcupine Abyssal Plain. This period was marked by the outpouring of pillows and flows of typical oceanic tholeiites, some of which were recovered at Site 550. At the same time, the seaward edge of the continental crust appears to have been deeply intruded by oceanic tholeiites, forming an intermediate crust of transitional geophysical characteristics.

Post-rift sedimentation started in the early Albian, and was accompanied by continuous regional subsidence. Before the Campanian, variable depositional environments produced quite diverse sedimentary sequences in the isolated halfgrabens. Carbonaceous shales were recovered in Cenomanian strata of the deepest site (550) and in lower Turonian beds at sites of intermediate depth (549-551). Depositional environments became more uniform across the margin after the late Campanian, and sedimentation was clearly influenced by more regional or global oceanographic events. Sea-level oscillations, climatic variations, changes in bottom circulation, and vertical fluctuations of the carbonate compensation depth $(C C D)$ were responsible for lithologic changes and major hiatuses.
\end{abstract}

\section{INTRODUCTION}

The primary objective of DSDP-IPOD Leg 80 was to obtain as complete a record as possible of the depositional and structural history of a sediment-starved continental margin in the northeastern Atlantic. Goban Spur was selected for drilling because it is one of the few areas in the Atlantic where relatively shallow open-hole drilling can reach syn-rift strata. The thin sediment cover in this region contrasts dramatically with the thick $(>10$ $\mathrm{km}$ ) depositional prism of the opposing North American continental margin.

Goban Spur is a submarine plateau $250 \mathrm{~km}$ southwest of the Irish mainland. It appears to be the southwestward extension of the Cornubian Platform, which separates the Celtic Sea Basin from the Western Approaches Basin on the adjacent European shelf (Figs. 1 and 2). The Spur descends gently southwest down to $2500 \mathrm{~m}$ water depth, where it is sharply truncated at Pendragon Escarpment. West of Pendragon Escarpment,

\footnotetext{
${ }^{1}$ Graciansky, P. C. de, Poag, C. W., et al., Init. Repts. DSDP, 80: Washington (U.S. Govt, Printing Office)

2 Addresses: (Graciansky) École Nationale Supérieure des Mines, 60 Bd St. Michel, 75272 Paris Cedex, France; (Poag) U.S. Geological Survey, Woods Hole, MA 02543.
}

low hills occupy depths of 3500 to $4000 \mathrm{~m}$. Farther southwest, an unnamed escarpment, 400 to $500 \mathrm{~m}$ high, forms the eastern rim of the Porcupine Abyssal Plain.

Two drill sites (548 and 549) are located on the thinned continental crust; one (550) is on the ocean crust, and one (551) is on a volcanic basement high, close to the continent-ocean boundary. (Table 1 summarizes operational coring data.) Sites 548 and 549 revealed for the first time the age and nature of the Hercynian basement in this region. The most important result at the medium-depth site (549) was coring a thick shallow-water sequence of Barremian syn-rift sediments. The abyssalplain site (550) is located $135 \mathrm{~km}$ east of magnetic Anomaly 33-34, where we recovered upper Albian ocean crust. Site 550 provides a nearly continuous, well-dated stratigraphic record that accumulated chiefly above the carbonate compensation depth (CCD).

In conjunction with other (DSDP-IPOD) sites previously drilled (Sibuet et al., 1980; Montadert, Roberts, et al., 1979), and with the help of a relatively dense seismic reflection grid, the four Leg 80 drill sites allow an accurate assessment of the structural evolution and depositional history of the continental margin of northwest Europe. The transect approach to drilling has been especially suitable for delineating the lateral relationships 
Table 1. Leg 80 drill site summary.

\begin{tabular}{llcccccccc}
\hline Hole & $\begin{array}{c}\text { Dates } \\
\text { on hole } \\
(1981)\end{array}$ & $\begin{array}{c}\text { Latitude } \\
(\mathrm{N})\end{array}$ & $\begin{array}{c}\text { Longitude } \\
(\mathrm{W})\end{array}$ & $\begin{array}{c}\text { Water } \\
\text { depth } \\
(\mathrm{m})\end{array}$ & $\begin{array}{c}\text { Penetration } \\
(\mathrm{m})\end{array}$ & $\begin{array}{c}\text { Number of } \\
\text { cores }\end{array}$ & $\begin{array}{c}\text { Cored } \\
(\mathrm{m})\end{array}$ & $\begin{array}{c}\text { Recovered } \\
(\mathrm{m})\end{array}$ & $\begin{array}{c}\text { Recovery } \\
(\%)\end{array}$ \\
\hline 548 & & & & & & & & &
\end{tabular}

among depositional environments and depositional sequences.

\section{REGIONAL GEOLOGIC SETTING}

\section{Physiography}

Goban Spur separates the northwest-trending Celtic margin from the north-trending Porcupine Basin (Figs. 1 and 2). The Celtic margin, constituting the northern continental margin of the Bay of Biscay, is the conjugate margin, in pre-spreading reconstruction, of the north Iberian margin (see Lefort, this vol.). Goban Spur and Porcupine Bank, in contrast, are conjugate to the Newfoundland margin (Flemish Cap) of Canada.
The general physiography of the continental slope defines several provinces that correspond roughly to underlying geological structures (Roberts et al., 1981; Montadert, Roberts, et al., 1979; Figs. 1 and 2). The narrow, steep Armorican Margin is bounded to the southwest by the deep Mesozoic-Cenozoic Armorican Marginal Basin. The Western Approaches Basin intersects the basin of the northern Bay of Biscay near Black Mud Canyon. The continental slope is cut by several submarine canyons that trend obliquely downslope. The regularity of the slope here is also interrupted by features such as $\mathrm{Me}$ riadzek Terrace (drilled during Leg 48 [Site 400]).

The north and south flanks of Goban Spur are asymmetrical. The southern flank is marked by the long and

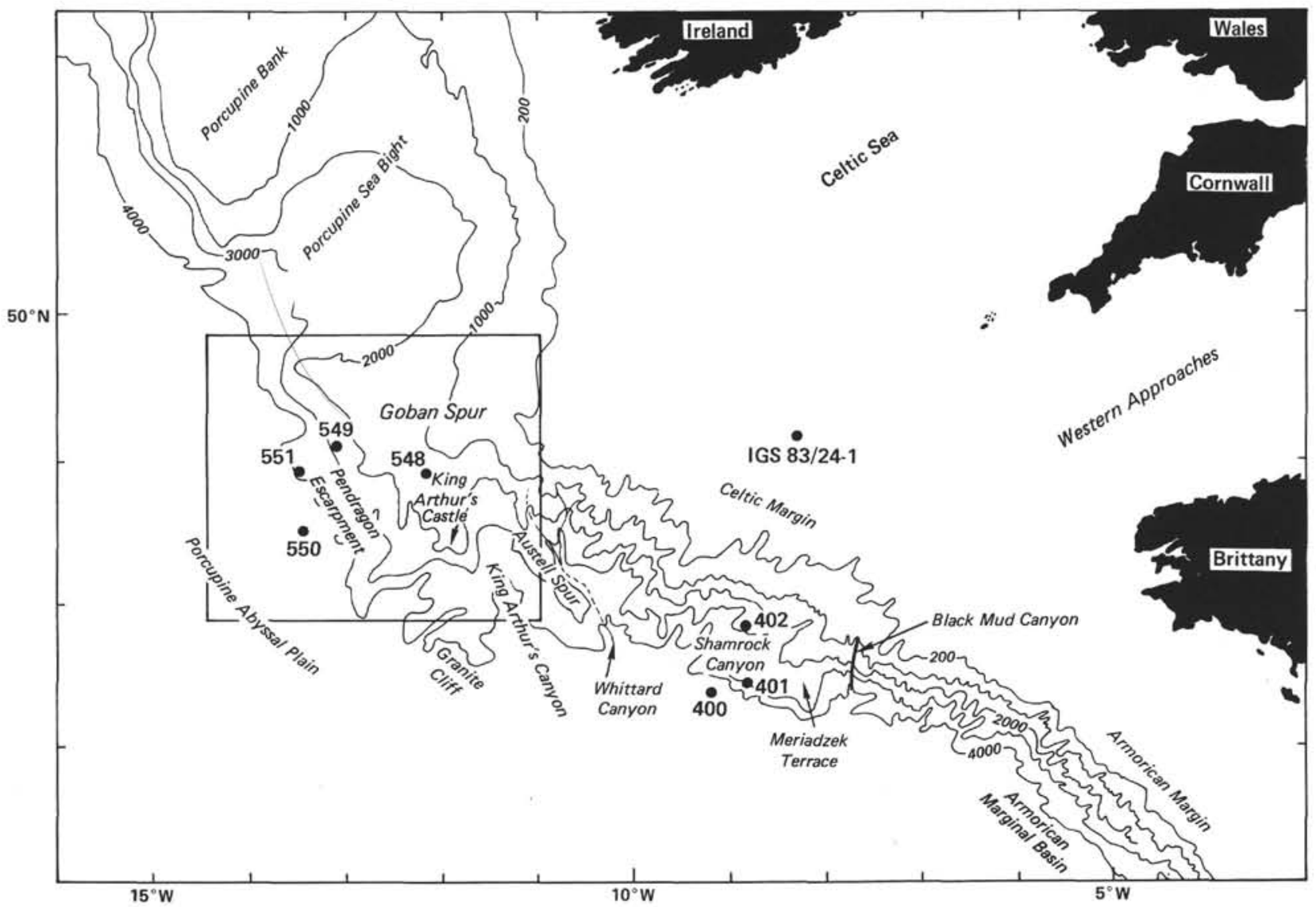

Figure 1. Generalized bathymetry (meters) of the continental margin southwest of Britain and Ireland, showing locations of Sites $548-551$ (from Masson et al., this vol.). Inset is Figure 2. 


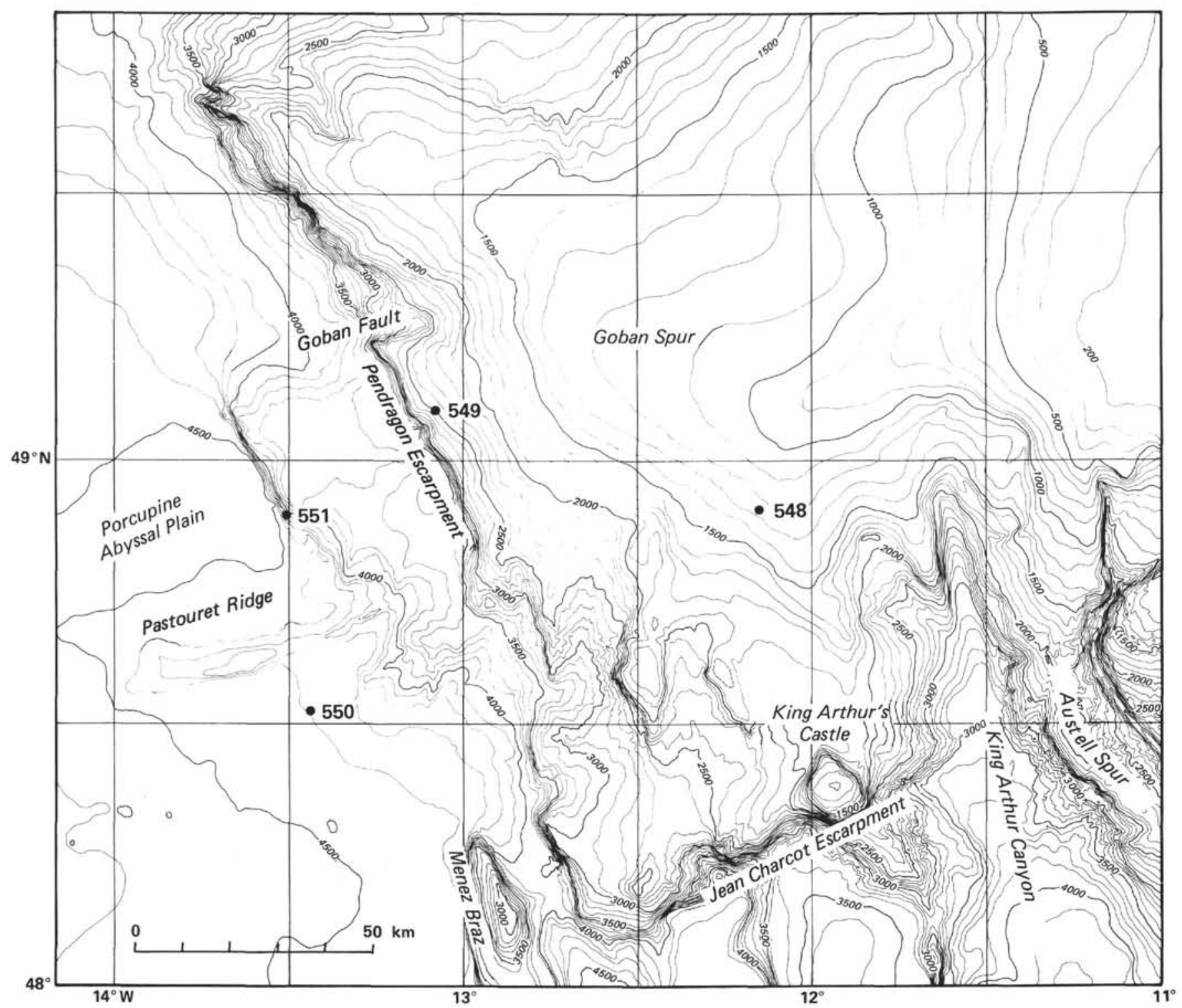

Figure 2. Inset of Figure 1. Seabeam bathymetric map at the Goban Spur and vicinity (from Sibuet et al., this vol.). (Depths in meters.)

steep Jean Charcot fault-scarp (Fig. 2); it is deeply incised by Whittard and King Arthur canyons, which border Austell Spur. Several protruding topographic features, such as Granite Cliff and King Arthur's Castle, extend the southern edge of Goban Spur toward the southeast (Fig. 2). The northern flank of Goban Spur is a smooth gentle slope leading down into Porcupine Sea Bight.

The Porcupine Sea Bight is bounded east and west by north-trending faults (Fig. 3). To the north it is bounded by Slyne Ridge. It connects with Porcupine Abyssal Plain by a narrow and deep depression $(3000-4000 \mathrm{~m}$ water depth), which is bounded to the north by Porcupine Bank and to the south by Goban Spur.

\section{Regional Structure}

The northwest Europe continental margin has been involved in several phases of rifting, drifting, and convergence between Europe, Iberia, and North America. The structure of Goban Spur resulted chiefly from the rifting of Europe from North America. Goban Spur was not involved in the more complex tectonic history of the Iberian region, but it was involved in compressional tectonism during the Eocene (Pyrenean tectonism).

The structural features of the northwest European continental margin are chiefly controlled by two distinctive, nearly perpendicular fault systems that have created a complex series of horsts and grabens within the continental crust. Over the positive blocks (e.g., Cornubian Platform), sediment cover is thin and contains numerous unconformities. Grabens (and half-grabens) are filled with thick Mesozoic and Cenozoic sedimentary deposits.

One fault system trends roughly northeast and bounds the elongated basins (Celtic Sea, Fastnet, Bristol Channel, and Western Approaches basins) that occupy the western shelf of Britain and Ireland. Some of these basins are partly exposed on the adjacent coastline of England and Scotland, but others are entirely offshore (Fig. 3). The syn-sedimentary fault activity that created 


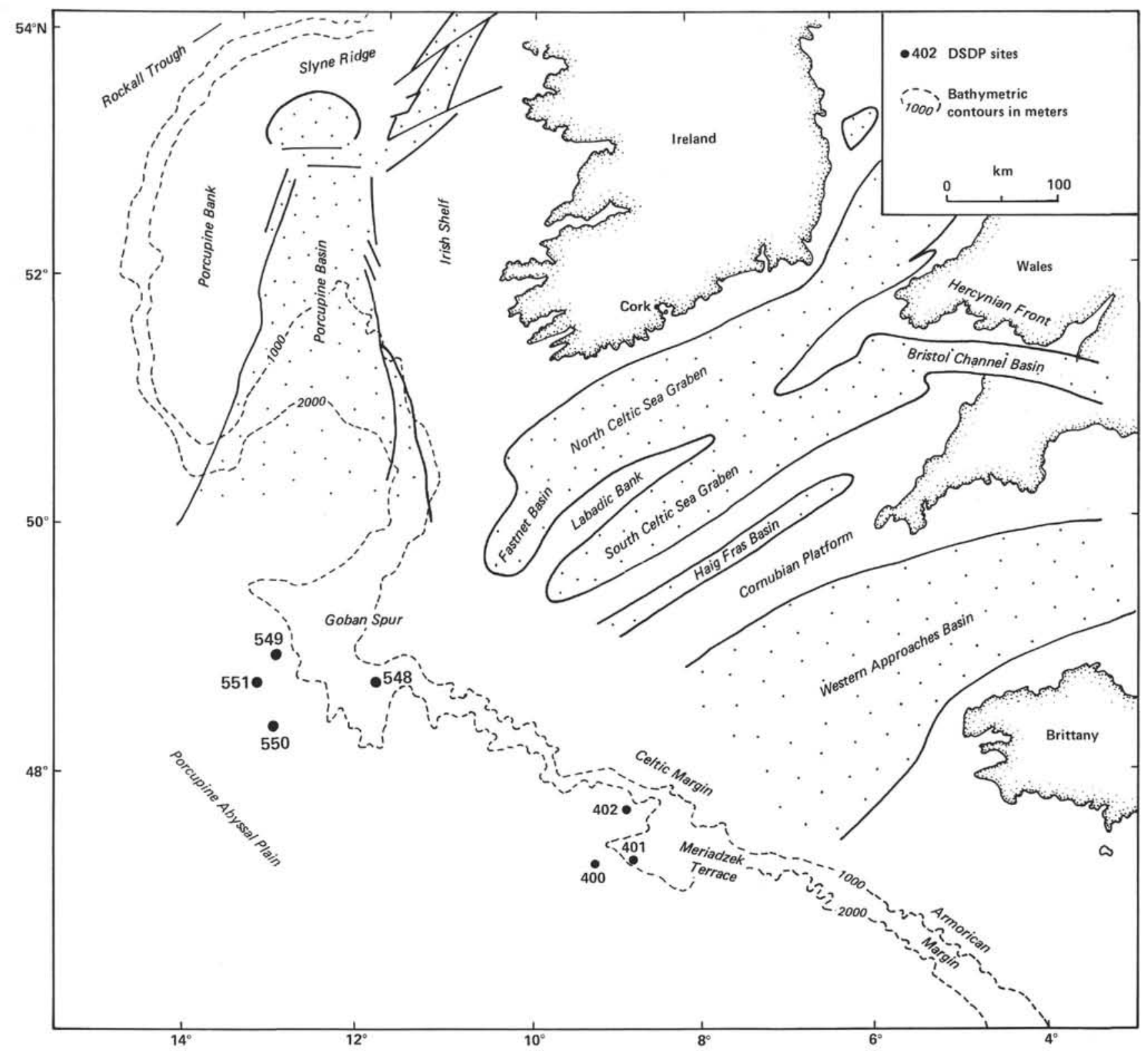

Figure 3. Sketch map showing the location of Goban Spur in relation to adjacent sedimentary basins (modified from Naylor and Shannon, 1982).

these basins started in the late Paleozoic and persisted through the Jurassic as a result of tensional tectonics (Ziegler, 1981). The faulting probably corresponded to rejuvenation of Caledonian structural trends (Sibuet et al., this vol.).

A second fault system trends northwest, and is particularly concentrated beneath the present continental slope and in the Fastnet Basin (Robinson, 1981; Figs. 2 and 3 ). This system originated as dextral shear faults in the late Permo-Triassic, extending from the Bay of Biscay to the western margin of Greenland (Lefort, this vol.). During the Permian to Triassic tensional phase, northwest- and northeast-trending faults were of the conjugate normal and shear types. But since approximately the Late Jurassic, the northwest-trending faults have been principally extensional features (chiefly listric normal faults).
The style of extensional tectonics in this region is now well known (Montadert, Roberts, de Charpal, et al., 1979; Bally et al., 1981; Montadert, Roberts, Auffret, et al., 1977), and is only briefly reviewed here (Fig. 4). Most of these extensional faults dip westward toward the ocean, having throws of as much as 3 to $4 \mathrm{~km}$. Continental basement blocks separated by the faults have been rotated and tilted during the extensional process. The raised edges of higher blocks are characterized by flat, horizontal surfaces planed by subaerial erosion (Montadert, de Charpal, et al., 1979). This rotation created asymmetric wedge-shaped basins (half-grabens), which are filled with syn-rift sediments. The faults of Goban Spur are mainly of this northwest-trending group.

The dense network of seismic profiles (Masson et al., this vol.; Fig. 3) shows that the complexity of the northwest-trending fault system on Goban Spur increases to 


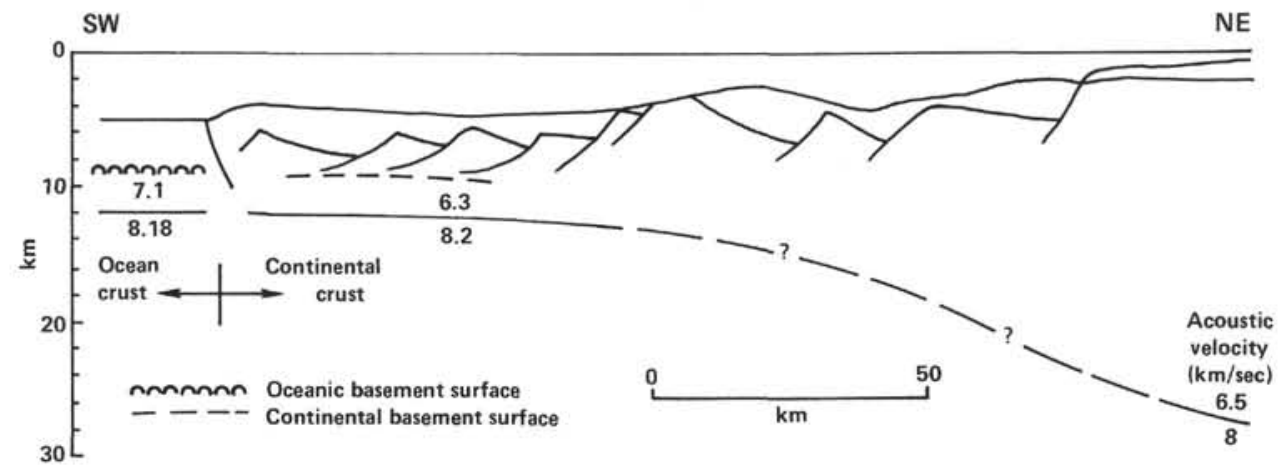

Figure 4. Schematic crustal section through the Armorican continental margin (from Roberts and Montadert, 1979).

the southeast, where the faults are less continuous and their orientations more variable, and several faults are downthrown to the northeast. This change in structural style is ascribed by Masson et al. (this vol.) to the differences in composition of shallow basement rocks. The more complex fault pattern in the south may be related in part to the presence of granite intrusions (these intrusions have been sampled by dredging and inferred from geomagnetic surveys; Pautot et al., 1976). Another factor causing increased fault complexity toward the southeast part of Goban Spur may be the junction of northwest-trending fault systems with east-trending fault systems near the Jean Charcot Escarpment (Fig. 2; Sibuet et al., this vol.).

\section{Regional Gravity and Geomagnetic Patterns}

Prominent, broad, northeast-trending gravity (freeair anomaly) minima coincide with the deep Celtic Sea and the Western Approaches basins (Fig. 5). Other small northeast-trending gravity minima are superimposed on the main gravity high of the Cornubian Platform. Beyond the shelf edge, the most significant gravity anomaly is a linear positive anomaly corresponding to a basement ridge (Guennoc et al., 1978; Scrutton, 1979 and this vol.).

A major change in the geomagnetic anomaly pattern (change in wavelengths) of the northeastern Atlantic takes place near the base of the continental slope (Roberts and Jones, 1975; Guennoc et al., 1978). This change reflects the transition between continental and ocean crust (Fig. 6). Within the continental domain, Hercynian basement sedimentary rocks are weakly magnetized. The magnetic character varies considerably, reflecting the grain of the underlying Caledonian basement and of the younger horsts and grabens (Roberts et al., 1981). West of Goban Spur and Porcupine Bank, basement igneous rocks are highly magnetized, and produce prominent northwest-trending anomalies characteristic of ocean crust.

The anomaly closest to the physiographic edge of Goban Spur was believed to be Anomaly 32 by Williams (1972) and later identified by Kristoffersen (1978) as Anomaly "34". The discovery of uppermost Albian sediments covering the basalts at Site 550, near the supposed continental-ocean crust boundary, is compatible with Kristoffersen's identification (Masson et al., this vol.).

The change in magnetic character from ocean to continent is not sharp enough to define the boundary precisely. Moreover, the boundary based on the change of magnetic-anomaly character does not coincide with that deduced from seismic reflection analysis. Modeling from magnetic and gravimetric data has led Scrutton (this vol.) and Masson et al. (this vol.) to recognize a $10-\mathrm{km}$ wide transitional zone separating ocean crust from continental crust.

\section{Seismostratigraphy}

The dense network of seismic reflection profiles over Goban Spur and adjacent areas (Masson et al., this vol.) includes $5150 \mathrm{~km}$ of multichannel profiles held by the Institute of Oceanographic Sciences (U.K.) and the Institut Français du Pétrole (France) and $6000 \mathrm{~km}$ of single-channel profiles held by the Institute of Oceanographic Sciences and the University of Edinburgh (U.K.). A post-cruise survey in the vicinity of Leg 80 drill holes added $1600 \mathrm{~km}$ of single-channel seismic reflection profiles (Sibuet et al., this vol.).

Typically, three types of broadly defined seismostratigraphic sequences have been recognized in the Goban Spur region:

1. Acoustic basement: At Goban Spur, the Hercynian acoustic basement has been broken and stretched by rifting. In adjacent shelf regions, the pre-rift basement comprises both the Hercynian basement and its pre-rift sediment cover. On ocean crust, the acoustic basement comprises basalt pillows and flows (e.g., Site 550). In some places, however, additional sedimentary strata may underlie the basalts (Masson et al., this vol.).

2. Syn-rift sequences: These sequences are present in wedge-shaped half-grabens, whose dipping internal reflectors suggest syn-sedimentary tilting of the seafloor, induced by the rotation of underlying basement blocks.

3. Post-rift sequences: The post-rift sequences are characterized by parallel or subparallel reflections that are draped over more complex sequences. Most of the post-rift sequences have not undergone any major tectonism. During the late Eocene, however, some old oceanic fracture zones were reactivated, as indicated, for 


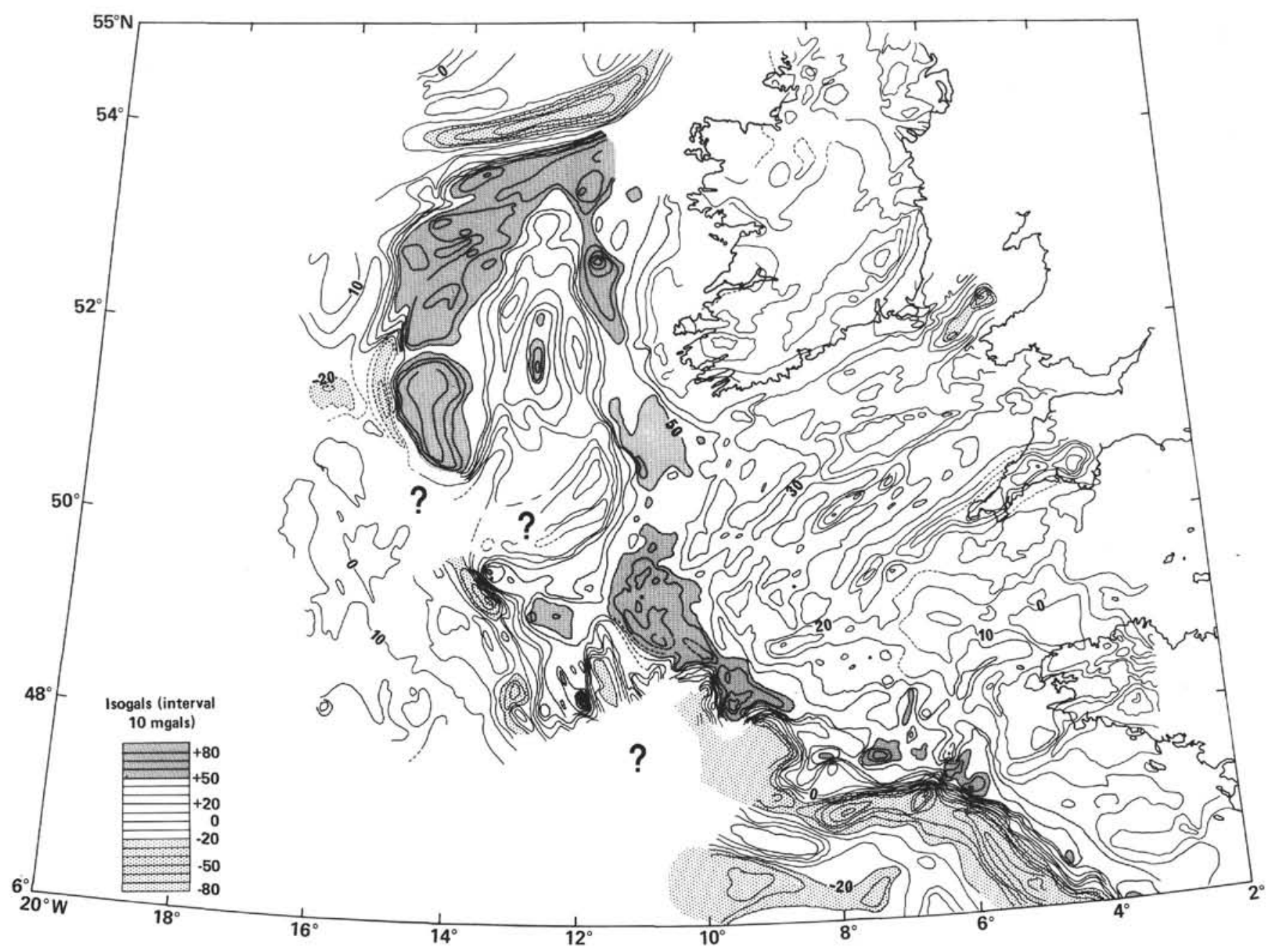

Figure 5. Free-air gravity anomaly map of the Celtic Sea and continental margin of the Western Approaches (from Roberts et al., 1981).

example, by the Pastouret Ridge at $48.7^{\circ} \mathrm{N}, 13.5^{\circ} \mathrm{W}$ (Fig. 2; Sibuet et al., this volume) and by a disconformity at Site 550 (seismic line CM 11; see Site 550 chapter, this vol.).

Correlation of seismic sequences with drilling results has been discussed in each of the site chapters and by Masson et al. (this vol.). The main results are summarized in the following sections and on Table 2.

\section{Acoustic Basement}

The top of continental basement is marked by a highamplitude reflector that displays several hundred meters of relief (Fig. 7). The basement is typically divided into rotated blocks separated by listric faults downthrown to the southwest. Our drilling results show that the continental basement of Goban Spur includes folded Devonian sandstones and shales. This confirms the results of previous dredging in the region (Auffret et al., 1979), which revealed that the basement crops out widely along seaward-facing scarps such as Pendragon Escarpment. This implies that the Caledonian-Hercynian basement is generally overlain by syn-rift or post-rift deposits with no lower Mesozoic pre-rift sediment cover interbedded.
The top of oceanic basement is marked by a highly diffractive surface close to Site 550 (seismic profiles CM 10, CM 11, OC 508; Site 550 chapter, this vol.; Masson et al., this vol.). Migrated profiles show that the basement surface is broken by a series of normal faults. Strong internal reflectors interpreted as thick lava flows appear to have been tilted between the faults (Masson et al., this vol.). Vertical displacement in excess of $1000 \mathrm{~m}$ is partly responsible for the rugged basement relief. Some of the faults displace the sediment cover, showing that tectonism was active within the ocean crust for an extended period after its accretion, especially during the Eocene tectonism.

The unnamed escarpment bordering the Porcupine Abyssal Plain west of Pendragon Escarpment forms the edge of a $15-\mathrm{km}$-wide terrace whose acoustic basement characteristics resemble those of the continental crust. The characteristic magnetic and gravimetric patterns of this basement segment can be traced several kilometers along the seaward edge of Goban Spur (Scrutton, this vol.). Masson et al. (this vol.) interpret this peculiar basement segment as the seaward edge of the original continental crust that was thinned during early rifting and 


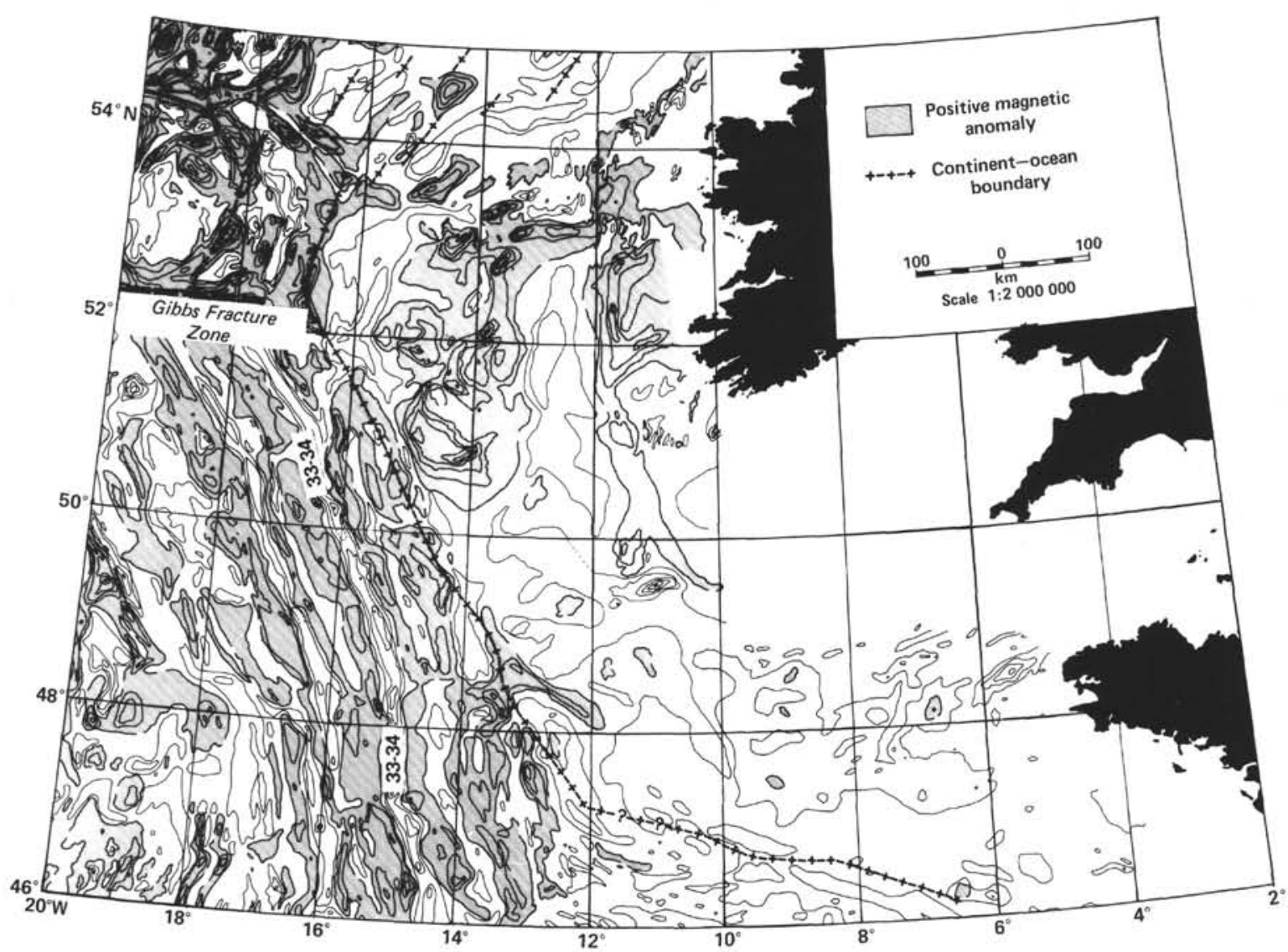

Figure 6. Magnetic anomaly map of the margin of northwest Europe. Contour interval 100 gammas (from Roberts and Jones, 1975).

deeply intruded by basalts during the later stages of rifting.

\section{Seismostratigraphic Sequences Above Basement}

The oldest seismostratigraphic sequence (Sequence 3), termed acoustic Formation 4 by Montadert, Roberts, et al. (1979), corresponds to the syn-rift deposits, characterized by wedge-shaped cross sections, divergent internal reflections, and syn-sedimentary faulting. This sequence lies unconformably upon the continental basement, and is marked at the top by the "breakup" or "post-rift" unconformity. Sequence 3 was drilled at Site 549 , where nearly $300 \mathrm{~m}$ of Barremian strata were penetrated (Fig. 8).

Northeast of Site 549 (see profile CM 10, Site 549 chapter, this vol.), the half-graben is filled by as much as $4 \mathrm{~km}$ of deposits belonging to Sequence 3 (Figs. 8 and 9). Masson et al. (this vol.) suggest that Barremian and Aptian strata constitute Sequence 3. Localized high-amplitude reflections within Sequence 3 may represent carbonate buildups (Masson and Roberts, 1981) and volcanic bodies (possibly sills; Masson et al., this vol.). These interpretations are supported by the results of dredging and observations using submersibles, which have documented Urgonian-like limestones and Lower Cretaceous volcanic rocks in Shamrock Canyon (Fig. 1; Pastouret et al., 1981).
At Site 548, post-rift sediments directly overlie the Caledonian-Hercynian basement, but farther to the northeast, as seen on seismic profile CM 11, a group of eastward-dipping reflections probably represents syn-rift fill. To the north of Goban Spur, seismostratigraphic Sequence 3 changes acoustic character and thickens considerably.

The distinction of four seismostratigraphic sequences in the Porcupine, Western Approaches, and Meriadzek basins is possible because mid-Cretaceous black shales are present at the base of the post-rift sequence. The characteristic transparent seismic signature of these shales is clearly recognizable to the south (Iberian to Armorican margins). These black shales constitute most of acoustic Formation 3 of Montadert, Roberts, et al. (1979) and Roberts et al. (1981).

In the Meriadzek area, the onset of post-rift deposition took place in the late Aptian (Montadert, Roberts, et al., 1979), whereas at Goban Spur (Site 549), the oldest post-rift strata sampled date from the early Albian.

The recognition and dating of the breakup unconformity is of primary importance, since it marks the end of continental rifting and the onset of seafloor spreading. Regional analysis of seismic profiles crossing the northwest Europe margin shows that this major unconformity generally seals the listric normal faults and separates two styles of deposition. The syn-rift strata have 
Table 2. Main seismostratigraphic sequences at Goban Spur.

\begin{tabular}{|c|c|}
\hline $\begin{array}{l}\text { Sequence } 1 \\
\text { (post-rift) } \\
\text { Holocene to } \\
\text { middle Eocene }\end{array}$ & $\begin{array}{l}\text { Holocene to Miocene: foraminifer-nannofossil } \\
\text { oozes and chalks (all sites) } \\
\text { Oligocene to middle Eocene: foraminifer- } \\
\text { nannofossil chalks (all sites) }\end{array}$ \\
\hline------- & --- Seismic discontinuity $--\cdots$ \\
\hline $\begin{array}{l}\text { Sequence } 2 \\
\text { (post-rift) } \\
\text { lower Eocene } \\
\text { to Albian }\end{array}$ & $\begin{array}{l}\text { lower Eocene to Paleocene: biosiliceous } \\
\text { nannofossil-bearing marls and ash layers } \\
\text { (all sites) } \\
\text { Maestrichtian to Campanian: foraminifer- } \\
\text { nannofossil chalks (all sites) } \\
\text { Santonian to Cenomanian: white chalks (Site } \\
\text { 549); dark shales (Site } 550 \text { ) } \\
\text { Albian: dark silty mudstones (Site } 549 \text { ); } \\
\text { limestones containing orbitolinids and } \\
\text { rudists (dredgings) } \\
\\
\text { Seismic discontinuity }\end{array}$ \\
\hline & Breakup unconformity \\
\hline $\begin{array}{l}\text { Sequence } 3 \\
\text { (syn-rift) } \\
\text { (?)Aptian and } \\
\text { Barremian }\end{array}$ & $\begin{array}{l}\text { (?)Aptian: not definitely sampled; possibly } \\
\text { red dolosparite at Site } 549 \\
\text { Barremian: pelagic foraminiferal silty mud- } \\
\text { stones; skeletal grainstones; brackish } \\
\text { sandstones and limestones (Site } 549 \text { ) }\end{array}$ \\
\hline & $---\begin{array}{c}\text { Seismic discontinuity } \\
\text { (Epi-Hercynian unconformity) }\end{array}-$ \\
\hline $\begin{array}{l}\text { Acoustic } \\
\text { basement }\end{array}$ & $\begin{array}{l}\text { Continental: Paleozoic metasedimentary rocks } \\
\text { (Sites 548, 549) } \\
\text { Oceanic: upper Albian tholeitic basalt (Site } \\
\text { 550) } \\
\text { Transitional: age uncertain-Paleozoic meta- } \\
\text { sedimentary (Site 551) }\end{array}$ \\
\hline
\end{tabular}

undergone syn-sedimentary deformation, but the postrift strata have not. The long-wave undulations conspicuous in the post-rift sequences are the result of differential deposition and of compaction above the high-relief fault-block topography.

The contact between post-rift and underlying deposits along the breakup unconformity is manifest in three ways: (1) in the deepest parts of the half-grabens, where sedimentation was fairly continuous, the contact is conformable but is still marked by a conspicuous seismic reflector; (2) where the sedimentary section thins toward the higher edges of basement blocks, an erosional unconformity truncates syn-rift strata (e.g., northeast of Site 548; Masson et al., this vol.); (3) on the flattened crests of the highest tilted blocks, post-rift sediments often rest directly upon the eroded Hercynian basement (e.g., Site 548).

On Goban Spur, seismostratigraphic Sequence 2 directly overlies the breakup unconformity. Sequence 2 is quite variable in seismic reflection characteristics and thickness; these relationships are addressed in detail elsewhere in this volume (site chapters; Masson et al., all this vol.).

Within the continental domain, the distribution and relative thickness of Sequence 2 was closely controlled by the underlying fault-block topography. The observed heterogeneity of coeval lithologies is the consequence of the relative sedimentary isolation of each half-graben during the early post-rift phase. Moreover, because the Leg 80 sites lie on the thin sediment sequences near the edges of the half-grabens, coring at these sites sampled some

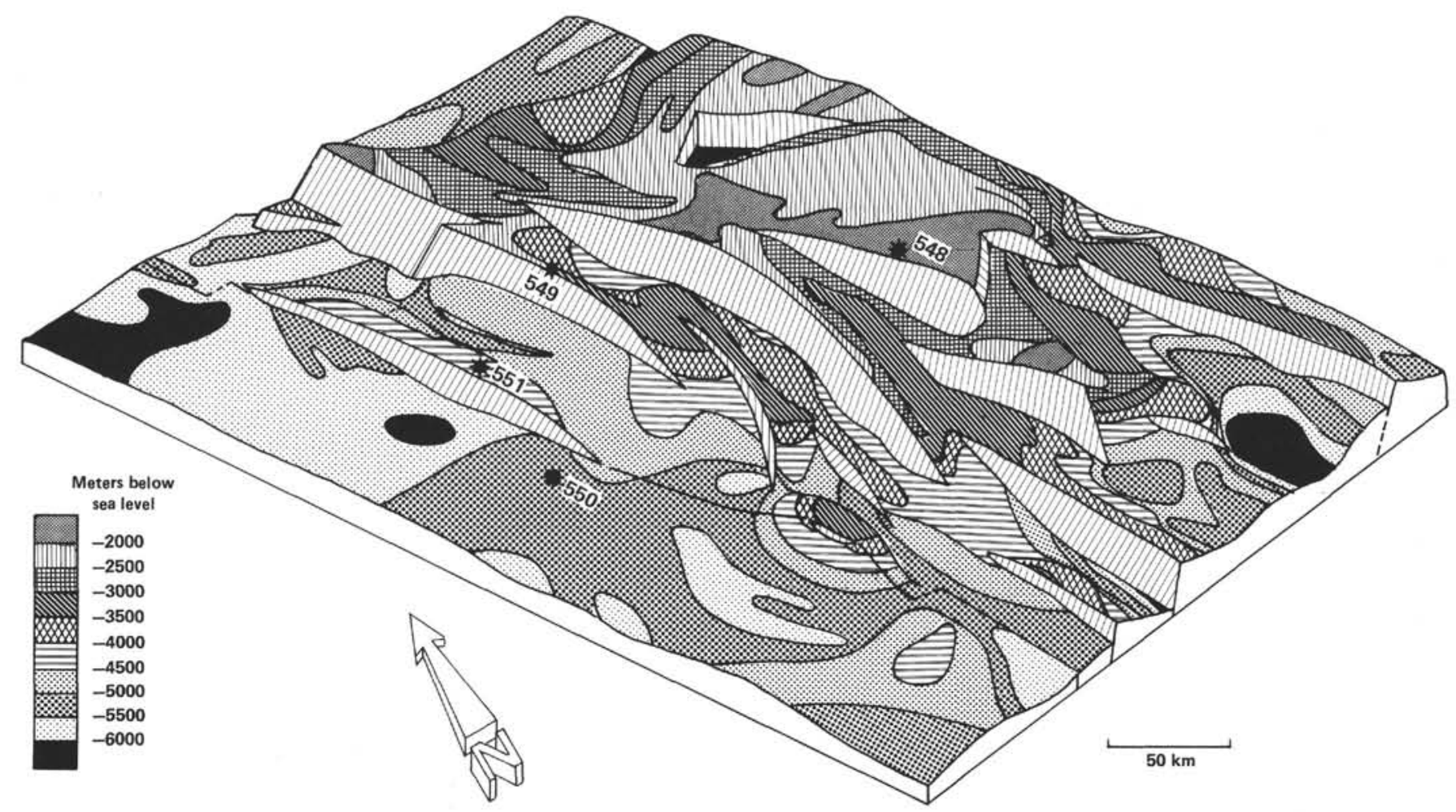

Figure 7. Schematic perspective of the basement surface stripped of its sediment cover (artwork adapted from Gillot, 1983). 

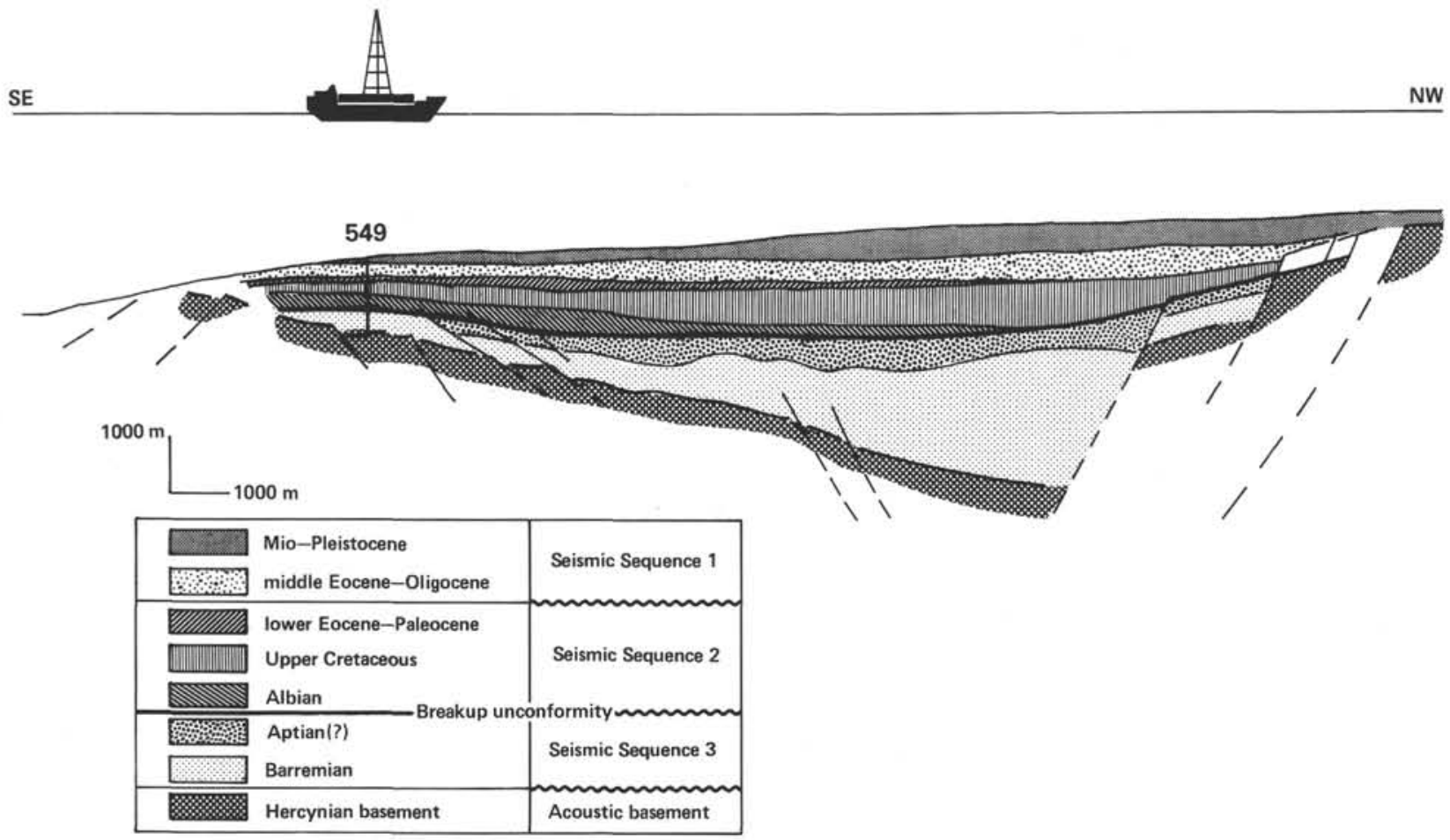

Figure 8. Interpretation of a segment of seismic line CM 10 where it crosses Site 549; vertical and horizontal scales equal.

peculiar lithologies and penetrated numerous unconformities. Correlation of Leg 80 sequences with thicker sequences lying in the axes of the half-grabens also entails some uncertainty.

Seismostratigraphic Sequence 1 is the youngest sequence drilled, and comprises the Cenozoic section, except for the lower Eocene and Paleocene, which are included within Sequence 2. Sequence 1 blankets the whole margin, having relatively constant seismic characteristics and relatively uniform thickness $(500-1000 \mathrm{~m})$, which suggests that the previous fault-block topography was smoothed by deposition of Sequence 2 (Fig. 8).

An erosional surface separates Sequences 1 and 2 on Goban Spur, but its correlation with the boundary between Formations 1 and 2 in the Meriadzek-Western Approaches regions appears to be somewhat diachronous (Masson et al., this vol.). This surface is probably of both eustatic and tectonic origin, since it corresponds to the unconformity which postdates the Eocene phase of folding (Sibuet et al., this vol.).

\section{SUMMARY OF DRILLING RESULTS}

\section{Site 548 (Holes 548 and 548A)}

The sedimentary section on the upper slope at Site 548 (1256 m water depth) was continuously cored to $551 \mathrm{~m}$ sub-bottom near the seaward edge of a tilted block of the Hercynian basement (Figs. 1 and 10). It bottomed in graphitic quartzites dated as Devonian by study of its acritarchs (Lefort et al., this vol.). We infer that the quartzitic basement surface has been truncated by subaerial erosion. After its subsequent inundation, sedimentation was very slow, allowing deposition of a phosphatic, calcareous hardground, indicative of upwelling.
Continuous post-rift deposition began in the late Campanian.

At this site, $530 \mathrm{~m}$ of upper Campanian to middle Miocene, outer sublittoral to upper bathyal foraminiferal nannofossil chalks grade to middle Miocene-Quaternary bathyal foraminiferal nannofossil oozes. Several significant unconformities were documented (Fig. 11), including (1) Danian (nannofossil Zones NP1-NP2 missing), (2) upper Danian-lower Thanetian (gap of 4 m.y.), (3) lower and middle Eocene (1-2 m.y. hiatus), and (4) middle Oligocene (nannofossil Zones NP23 and 24 missing; gap of 3-4 m.y.; Snyder et al., this vol.; Poag et al., this vol.). Lower Eocene chalks are more marly than the rest of the section; cherts are present in the middle Eocene.

The use of the new variable-length hydraulic piston corer (VLHPC) permitted the recovery of a nearly complete, 211-m section (recovery was 93\%) of Holocene through lower Pliocene nannofossil and marly nannofossil oozes in Hole 548. This section contains an exceptional record of climatic fluctuations. The initiation of glacial activity in the late Pliocene was marked by the influx of ice-rafted terrigenous sediments, including metamorphic pebbles. The upper boundary of a North Atlantic Deep Water (NADW)-like mass repeatedly migrated back and forth across Site 548 during the Neogene. The climatic fluctuations were relatively mild and gradual in the late Pliocene and early Pleistocene, but became more severe and rapid in the late Pleistocene.

\section{Site 549 (Holes 549 and 549A)}

Site 549 is located above the seaward tip of a tilted basement high (2335.5 m water depth) on the crest of Pendragon Escarpment (Figs. 1 and 10). A 1005.5-m 


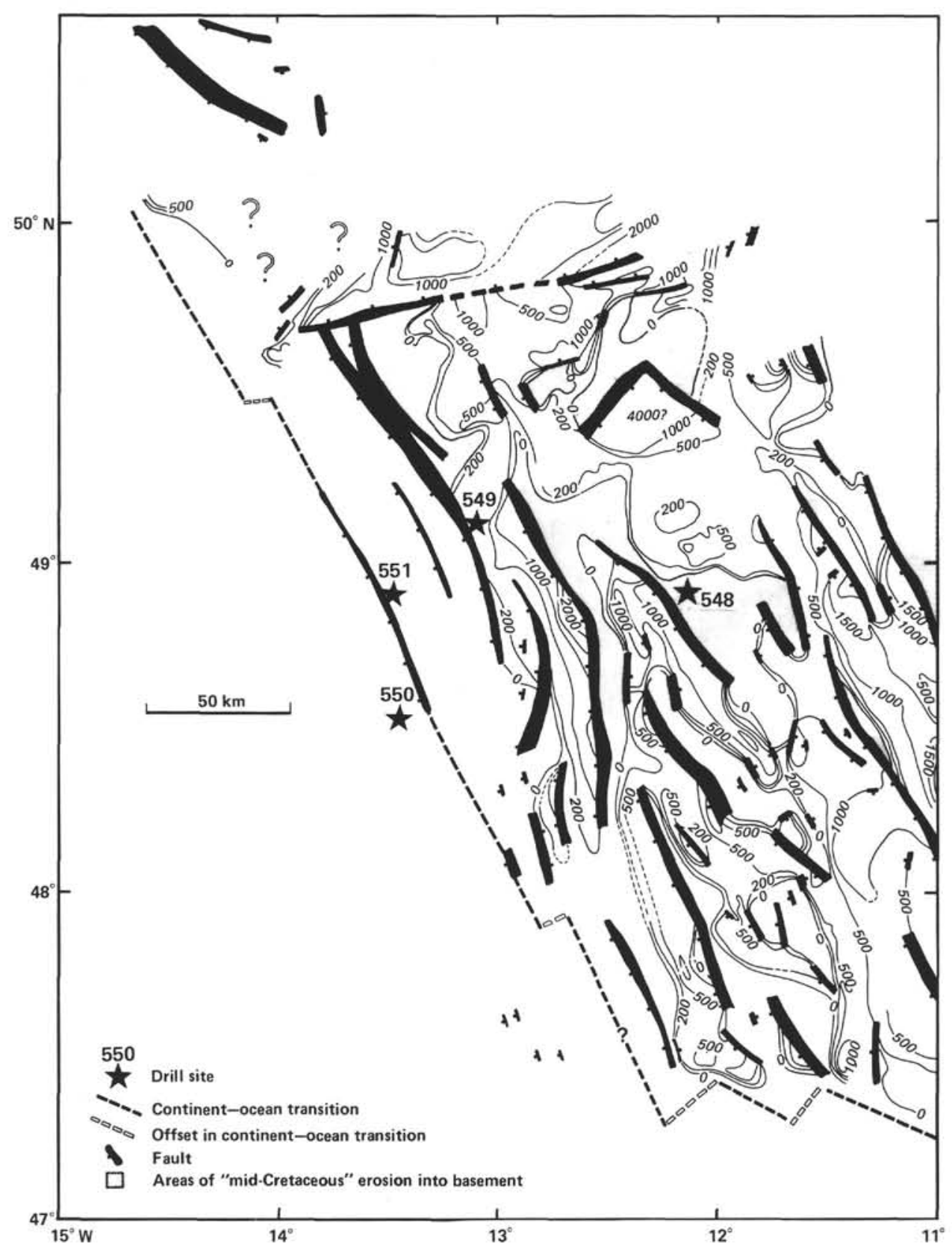

Figure 9. Distribution of syn-rift sediments in the Goban Spur area. Main accumulation of syn-rift sediment is in long, narrow, northwest-trending basins (from Masson et al., this vol.).

section was continuously cored, including a $37-\mathrm{m}$ penetration of Hercynian basement. This basement comprises foliated, micaceous sandstones, tentatively correlated with the Devonian Old Red Sandstone. The principal achievement at Site 549 was sampling a 290 -m-thick sequence of Barremian syn-rift deposits, comprising a threefold succession of (1) hyposaline shallow-water deposits grading upward to (2) calcareous skeletal packstones and wackestones, and then to (3) pelagic, calcareous, sandy mudstones deposited in outer sublittoral environments (Rat et al., this vol.).

Above a 9.7-m-thick bed of undated, possibly Aptian, sandy dolomite, the breakup unconformity separates the syn-rift sequence from Albian post-rift sediments.
The unconformity can be traced on seismic profiles across the broad half-graben east of Pendragon Escarpment. There it overlies a thick sequence whose geometry and seismic characteristics suggest Aptian deposits (Fig. 8).

The lower and middle Albian strata consist of $185 \mathrm{~m}$ of gray calcareous, silty mudstone containing planktonic foraminifers and radiolarians that were deposited in outer-shelf to upper-slope environments. The prevailing dark color is probably due more to disseminated micropyrite than to organic matter, which generally comprises less than $1 \%$.

The remaining post-rift section includes $479 \mathrm{~m}$ of Cenomanian to upper Miocene foraminiferal nannofossil chalks, overlain by $27 \mathrm{~m}$ of Pleistocene and Holocene 
marly calcareous nannofossil and foraminiferal nannofossil oozes. All were deposited in bathyal environments. The Upper Cretaceous sequence is relatively condensed. A 1-m interval of lowermost Turonian carbonaceous shale indicates temporary anoxia (maximum total organic carbon is $3.5 \%$; organic matter is of marine phytogenic origin) (Waples et al., this vol.). Upper Paleocene to lower Eocene brown and gray nannofossil chalks are richer in clay and silica than enclosing strata, owing to volcanic activity and terrigenous influx (Townsend, this vol.; Knox, this vol.). The thin Pleistocene to Holocene section is composed of marly calcareous nannofossil ooze and calcareous foraminiferal ooze, which were deposited below a NADW-like mass, as indicated by benthic foraminiferal evidence (Poag et al., this vol.). The site was too deep to be affected strongly by Pleistocene climatic fluctuations (Caralp et al., this vol.), but planktonic microfossils reflect the same climatic alternations noted at Site 548 (Pujol, this vol.).

The main unconformities encountered at Site 549 (Fig. 11) are (1) post-Hercynian unconformity; (2) breakup unconformity (Aptian? to Albian); (3) Cenomanian to Turonian (upper Cenomanian missing); (4) middle Maestrichtian; (5) Danian (hiatus of 4 m.y.); (6) lower Eocene (part of nannofossil Zone NP10 missing); (7) middle Oligocene (gap of 4-5 m.y.; part of nannofossil Zone NP23 missing); (8) uppermost Oligocene to lower Miocene (gap of 5 m.y.); (9) middle Miocene to upper Miocene (gap of 5 m.y.); (10) entire Pliocene and part of Pleistocene (hiatus of 3.5 m.y.); and (11) intra-Pleistocene.

\section{Site 550 (Holes 550 and 550A)}

Site 550 is located $10 \mathrm{~km}$ southwest of the seaward edge of Goban Spur (4432 m water depth), above a high structural block of oceanic basement (Masson et al., this vol.). Coring was continuous from 99 to $720.5 \mathrm{~m}$ sub-bottom, including $33 \mathrm{~m}$ of fairly fresh basalts at the bottom.

The volcanic sequence contains pillow lavas and hydroclastites in the upper part, underlain by several massive lava flows. These volcanics are porphyric, typical oceanic tholeiites, having well-preserved original textures and primary plagioclases and clinopyroxenes. Absolute age determinations were unsuccessful, owing to lowtemperature alteration in the "brownstone facies," which destroyed the glassy groundmass and the olivines (Maury et al., this vol.). A minimum age of Albian at the top of this volcanic sequence was obtained from study of nannofossils in pelagic calcareous interbeds. Bathyal to abyssal sediments directly overlying the basalts are uppermost Albian (Vraconian).

The early post-spreading deposits at Site 550 include $90.85 \mathrm{~m}$ of interbedded light and dark calcareous, silty mudstones, upper Albian to middle Cenomanian. A mixed suite of terrestrial and marine organic remains (total organic carbon content is $1-2.5 \%$ ) in the darker lithologies indicates periodically restricted circulation in the narrow basin. A carbonate-depleted interval (19-20 $\mathrm{m}$ thick) in the Coniacian-Santonian section, interbed- ded with chalky turbiditic layers, suggests temporary elevation of the CCD.

In the Cenozoic, a particularly notable section of brownish and grayish siliceous nannofossil chalk constitutes the upper Paleocene to upper Eocene section. Several bentonitic layers containing glass shards were derived from an episode of explosive volcanic activity (during deposition of nannofossil Zones NP4 to NP20), which also affected the North Sea and a wide area of northwest Europe (Knox, this vol.). This volcanic-sedimentary sequence is bracketed by metalliferous encrustments. The lower encrustment formed between nannofossil Zones NP4 and NP5, and is characterized by an accumulation of Mn-rich micronodules. The upper encrustment contains ash layers impregnated with $\mathrm{Mn}, \mathrm{Ba}, \mathrm{Ni}$, $\mathrm{Cu}$, and $\mathrm{Co}$, which accumulated during a period of slow sedimentation (nannofossil Zones NP14 to NP20; Karpoff et al., this vol.).

The upper part of the sedimentary section at Site 550 comprises $575 \mathrm{~m}$ of upper Campanian to Pleistocene argillaceous foraminiferal and nannofossil chalks, grading upward to oozes; all were deposited in abyssal environments.

The principal unconformities encountered at Site 550 (Fig. 11) are (1) upper Cenomanian to Turonian; (2) lower Campanian; (3) upper Danian (foraminiferal Zone P2 missing); (4) upper Paleocene (nannofossil Zones NP6, 7 , and 8 missing or extremely condensed); (5) middle Eocene to Oligocene (nannofossil Zones NP15 to NP25 severely condensed or partly missing); (6) lower-middle Miocene (nannofossil Zone NN4 probably missing); and (7) middle to upper Miocene (gap of 4-5 m.y.). The post-Pliocene record is incomplete because of discontinuous coring above $99 \mathrm{~m}$ sub-bottom.

\section{Site 551 (Hole 551)}

Hole 551 was drilled above the flat top of a raised basement block on the seaward edge of Goban Spur, $2 \mathrm{~km}$ east of the physiographic boundary of the continental margin (3909 m water depth; Figs. 1 and 10). The principal objective was to identify the composition and age of basement. Basement consists of basaltic flows and pillow lavas whose presence at this location had been predicted by Scrutton (1979) from magnetic and gravimetric data. The basalts are more altered here than at Site 550, but the petrographic, geochemical, and traceelement characteristics at both sites are very similar to those of oceanic tholeiites (Maury et al., this vol.).

The basalts are directly overlain by upper Cenomanian to Holocene bathyal foraminiferal nannofossil chalks and oozes. Spot coring in the upper $100 \mathrm{~m}$ of sediments and continuous coring in the lower $42.4 \mathrm{~m}$ of sediments above basalt yielded an abbreviated section of chiefly Eocene and Upper Cretaceous strata. The most notable lithology was a carbonaceous Turonian black shale, enriched in marine organic matter, equivalent to that recovered at Site 549 .

A major unconformity (20 m.y. hiatus) separates lower Turonian from upper Campanian deposits. Upper Maes- 


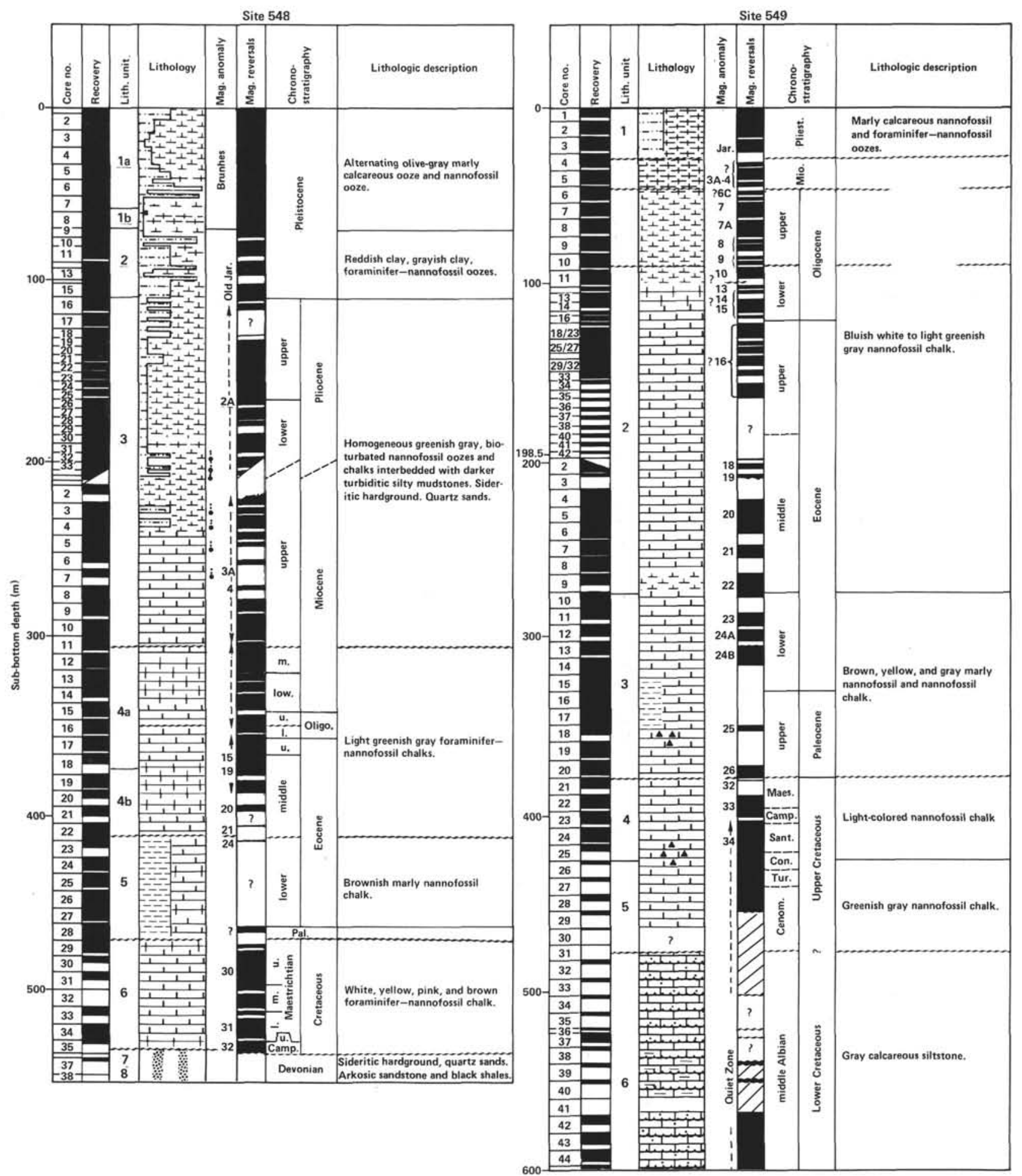

Figure 10. Geologic columns for Sites $548,549,550$, and 551 and structural position of each site.

trichtian and lower Paleocene strata are missing (nannofossil Zone NP9 directly overlies lower Maestrichtian chalks). The lower to middle Eocene section is at least $50 \mathrm{~m}$ thick, but recovery of the remaining Cenozoic strata was not sufficient to reconstruct that depositional history.

\section{STRUCTURAL AND DEPOSITIONAL HISTORY OF GOBAN SPUR}

\section{Paleozoic Relationships}

Our discussion of the pre-rift history of Goban Spur begins with North America, Western Europe, and Iberia 

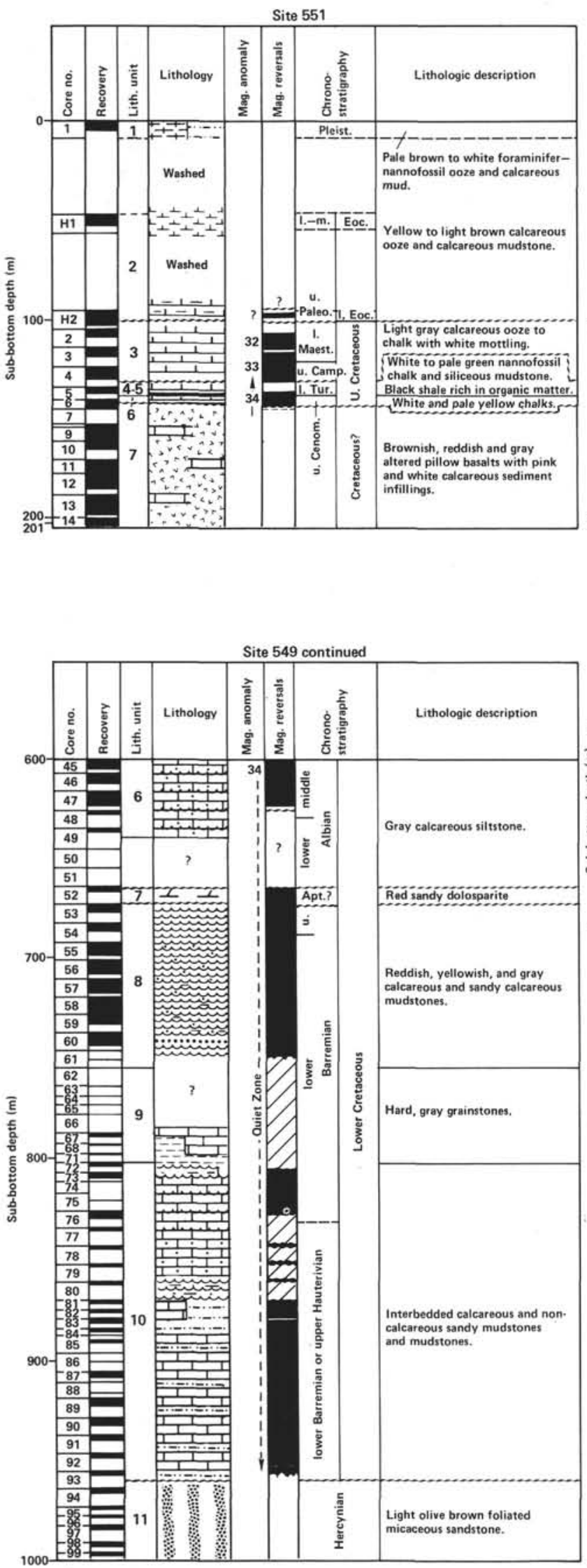

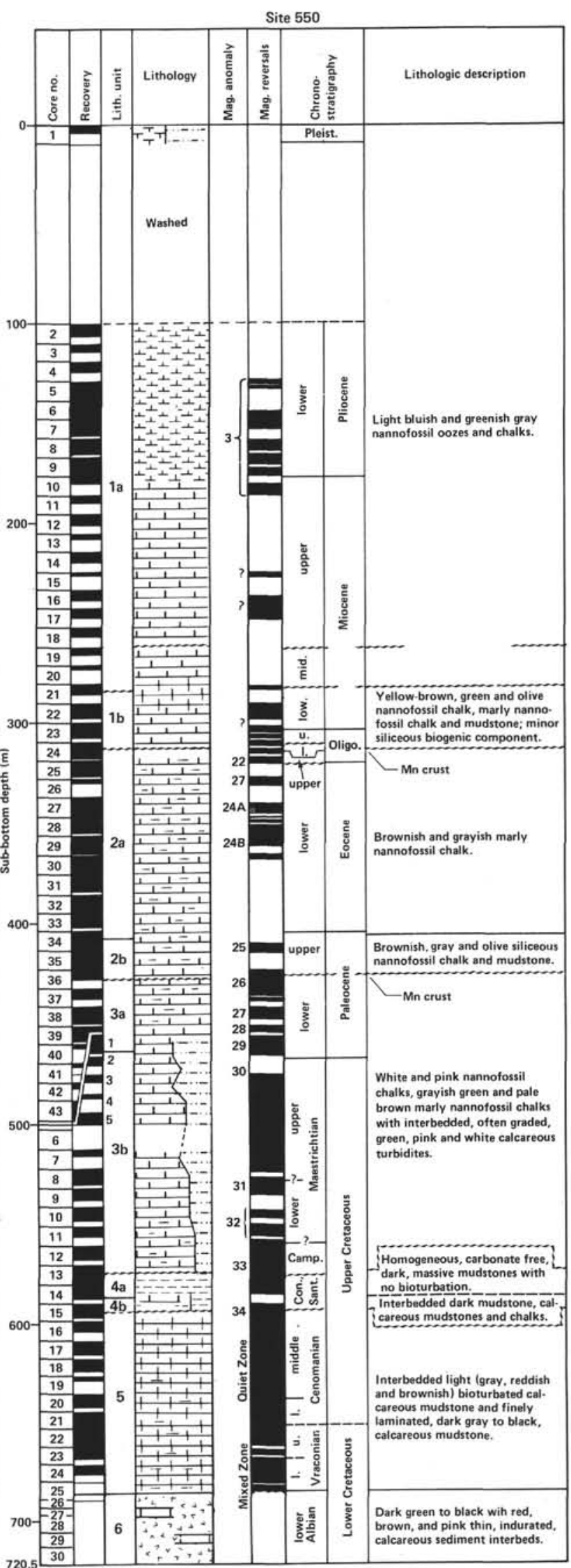

Figure 10. (Continued). 


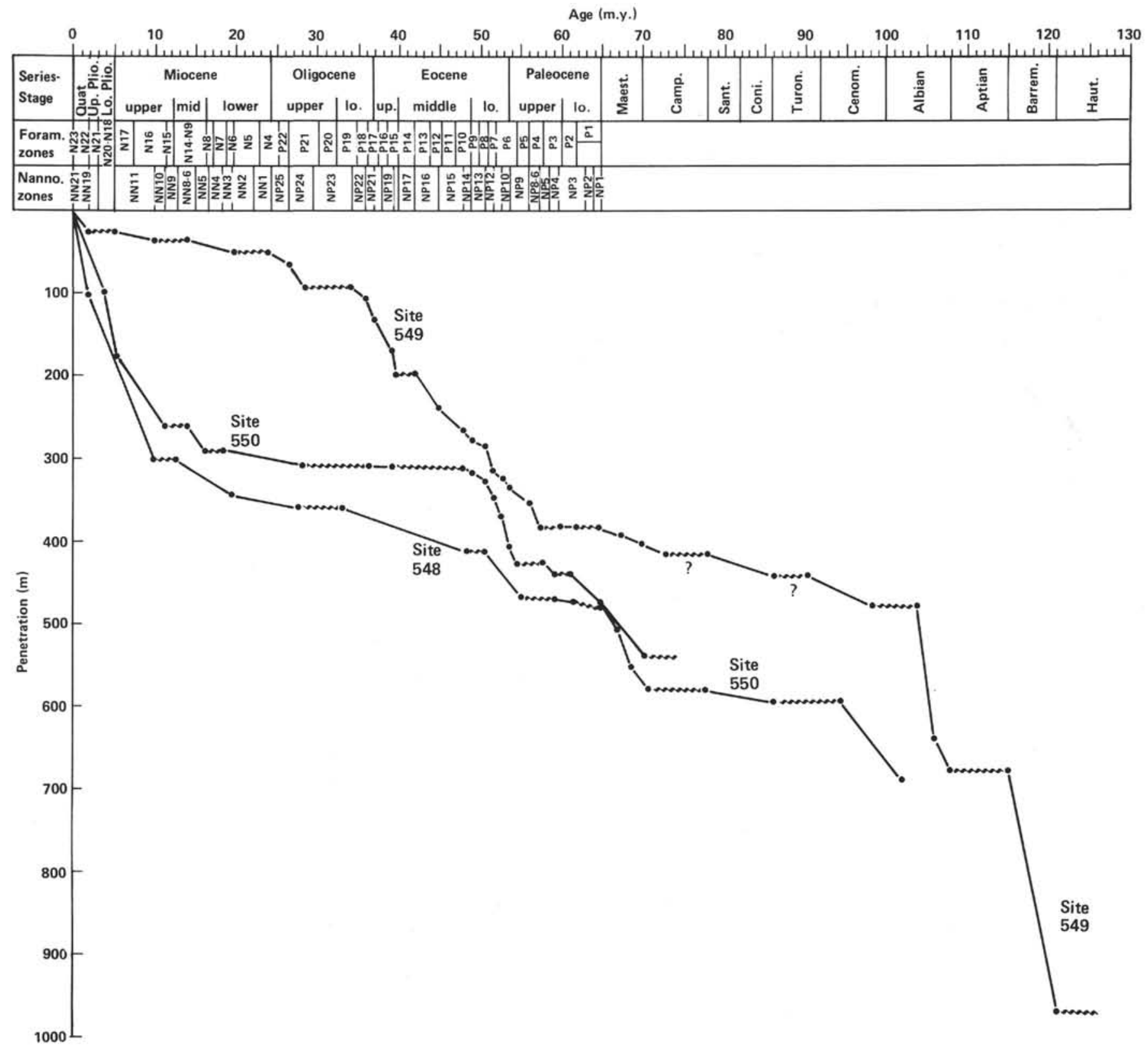

Figure 11. Curves of sediment accumulation rate for Goban Spur transect sites.

joined together as a part of Gondwanaland after the Hercynian orogeny. The pre-Atlantic reconstruction is difficult to achieve with confidence, because of uncertainties as to the exact mechanisms and amounts of listric and shear faulting by which the continental crust was stretched during the late Paleozoic and Triassic (Kay, 1969; Lefort, 1973). The following structural markers can be used to correlate the pre-Mesozoic basement on both sides of the Atlantic: (1) widescale concentric arches, dated Cadomian (Late Precambrian), between the Avalon Peninsula (eastern Newfoundland), Iberia, and the Armorican margin; (2) the suture of the Iapetus Ocean, which formed the Northern Appalachian belt in middle Paleozoic time; (3) the suture of the Theic Ocean, which formed the Acadian and Hercynian belts in the late Paleozoic; and (4) the Hercynian front, which runs through southern Wales, southern Ireland (Fig. 3), and northern Newfoundland (Lefort et al., this vol.).

The weak cleavage and the moderately good preservation of organic fossils documented within Devonian basement rocks at Sites 548 and 549 indicate low-grade metamorphism. Therefore, Goban Spur and Flemish Cap, its preopening Hercynian counterpart, are probably located north of the main Hercynian metamorphic belt of Europe and south of important Hercynian regional deformation seen in Ireland (Lefort et al., this vol.). The discovery of Devonian carbonaceous quartzites at Site 548 and Old Red Sandstone equivalents at Site 549 also fixes the tentative southern limit between the non-marine Old Red landmass of Ireland and Newfoundland and the shallow-marine Devonian deposits of Cornwall and Brittany (Lefort et al., this vol.). Dredging results 
indicate that the low-grade metamorphic rocks of the Hercynian basement have been intruded by granitic magmas along a trend running from Cornwall to the Granite Cliff (Pautot et al., 1976; Sibuet, 1973).

The basement structures on both sides of the Atlantic have been sheared in two successive phases:

1. First, a complex pattern of conjugate shear faults and related pull-apart structures (Arthaud and Matte, 1975) developed during the late Stephanian and Autunian (Late Carboniferous and early Permian) along reactivated Caledonian lineaments. The network of faults caused the subsidence of wrench-related basins and the extrusion of thick volcanic sections, such as in the Oslo rift. This fault system so strongly fragmented the Hercynian fold-belt (except for the Appalachians and Urals) that it ceased to play a major role as a cohesive tectonic unit.

The Porcupine and Western Approaches basins probably began to form during the Stephanian-Autunian faulting, although there is some uncertainty as to the presence of Permian strata at the base of thick red bed sequences in those basins (Naylor and Mounteney, 1975). The role of the reactivation of old Caledonian structures in the delineation of the Porcupine Sea Bight was pointed out by Max (1978). On both sides of the future Atlantic, these late Paleozoic faults were marked by a shear zone, trending east-west, that stretched $3000 \mathrm{~km}$ between the Hercynian front and the South Atlas Fault (Lefort, this vol.; Fig. 12).

2. The second phase of regional shearing began in the Permo-Triassic, cutting across the Stephanian-Autunian framework and forming a complex system of grabens, such as the Bay of Biscay rift, the Western Approaches Basin, the Celtic Sea Basin, the Porcupine Trough, and several North Sea grabens (Ziegler, 1981; Naylor and Shannon, 1982; Figs. 13 and 14). In some of these basins, Permo-Triassic beds may be several thousand meters thick. The Bay of Biscay rift system extended northwestward toward the Labrador Sea, but was probably better developed on the European side (Lefort, this vol.; Fig. 12B). Volcanic rocks are much less abundant than in the typical upper Paleozoic sections, but northwest-trending doleritic dikes, 190-205 m.y. old, are present in Brittany (Leutwein et al., 1972). These dolerites are indicative of tectonism that took place between latest Hercynian deformation and the Atlantic opening.

There is little or no early and middle Mesozoic sedimentary record on positive areas such as Goban Spur, the Cornubian Platform, and Labadie Bank, but the grabens contain thick Mesozoic and Cenozoic sections (as much as $2 \mathrm{~km}$ in the Western Approaches Basin [Avedik, 1975]; $5 \mathrm{~km}$ in the North Celtic Sea Basin [Colin et al., 1981]; $4 \mathrm{~km}$ in the Fastnet Basin [Robinson et al., 1981]). A succession of Jurassic transgressions and regressions recorded in these basins have been tentatively related to major tectonic events by Roberts et al. (1981), but are not related to the depositional history of Goban Spur.

\section{Mesozoic Rift Systems}

The proposed tectonic mechanisms for stretching the continental crust during pre-Atlantic rifting are varied and controversial. The model most frequently applied in the Goban Spur region incorporates brittle fracturing along listric normal faults in the upper crust and complementary thinning by ductile flow below. This would theoretically thin the crust as much as $18 \mathrm{~km}$ (de Charpal et al., 1978; Montadert, de Charpal, et al., 1979; Masson et al., this vol.; Figs. 4 and 15). The studies of Masson et al. (this vol.) support the models based on differential thinning between the upper and lower lithosphere. The major depositional effect of rifting was sedimentary thickening into the grabens as the basement blocks rotated downward along the listric faults.

The faults bounding the Goban Spur grabens parallel the present continental slope, and are spaced typically 5-20 km apart; maximum vertical displacement exceeds $4 \mathrm{~km}$. These northwest-trending faults probably formed through reactivation of a Permo-Triassic strike-slip network (Lefort, this vol.). The hypothesis that northeasttrending fractures might offset the main Goban Spur faults (Dingle and Scrutton, 1977; Montadert, Roberts, et al., 1979) is controverted by Masson et al. (this vol.). Nevertheless, the northern edge of Goban Spur is marked by a group of northeast-trending normal faults (Roberts et al., 1981). Additional northeast-trending faults have

A B

C

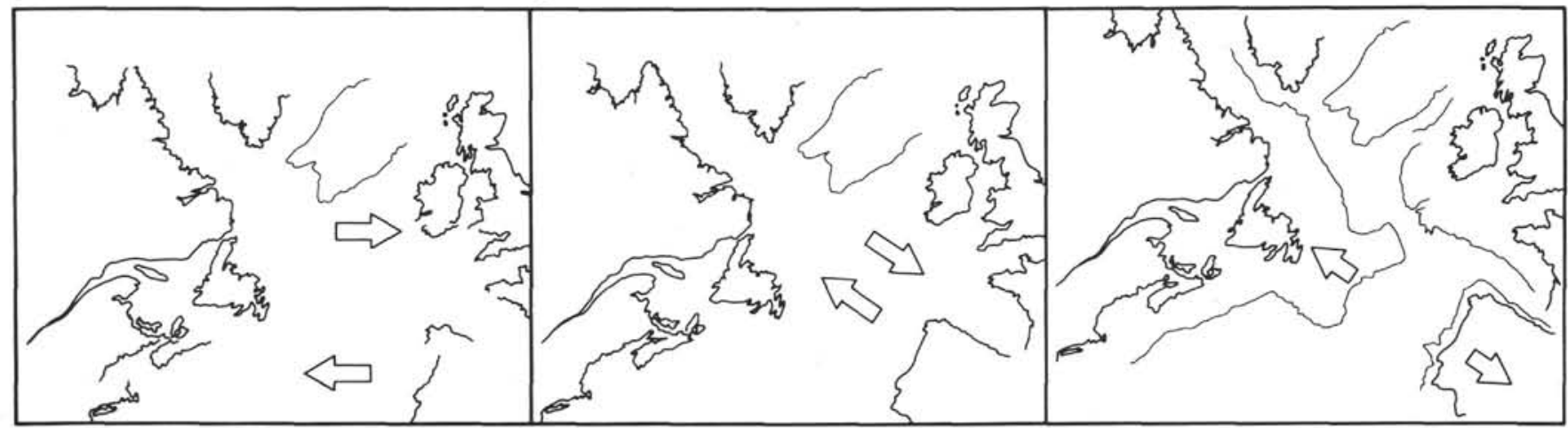

Figure 12. Crustal movements in the northeast Atlantic. Arrows denote relative direction of motion (Lefort, this vol.). A. Late Stephanian-early Permian (late Hercynian). B. Late Permian-early Triassic. C. Mesozoic. 


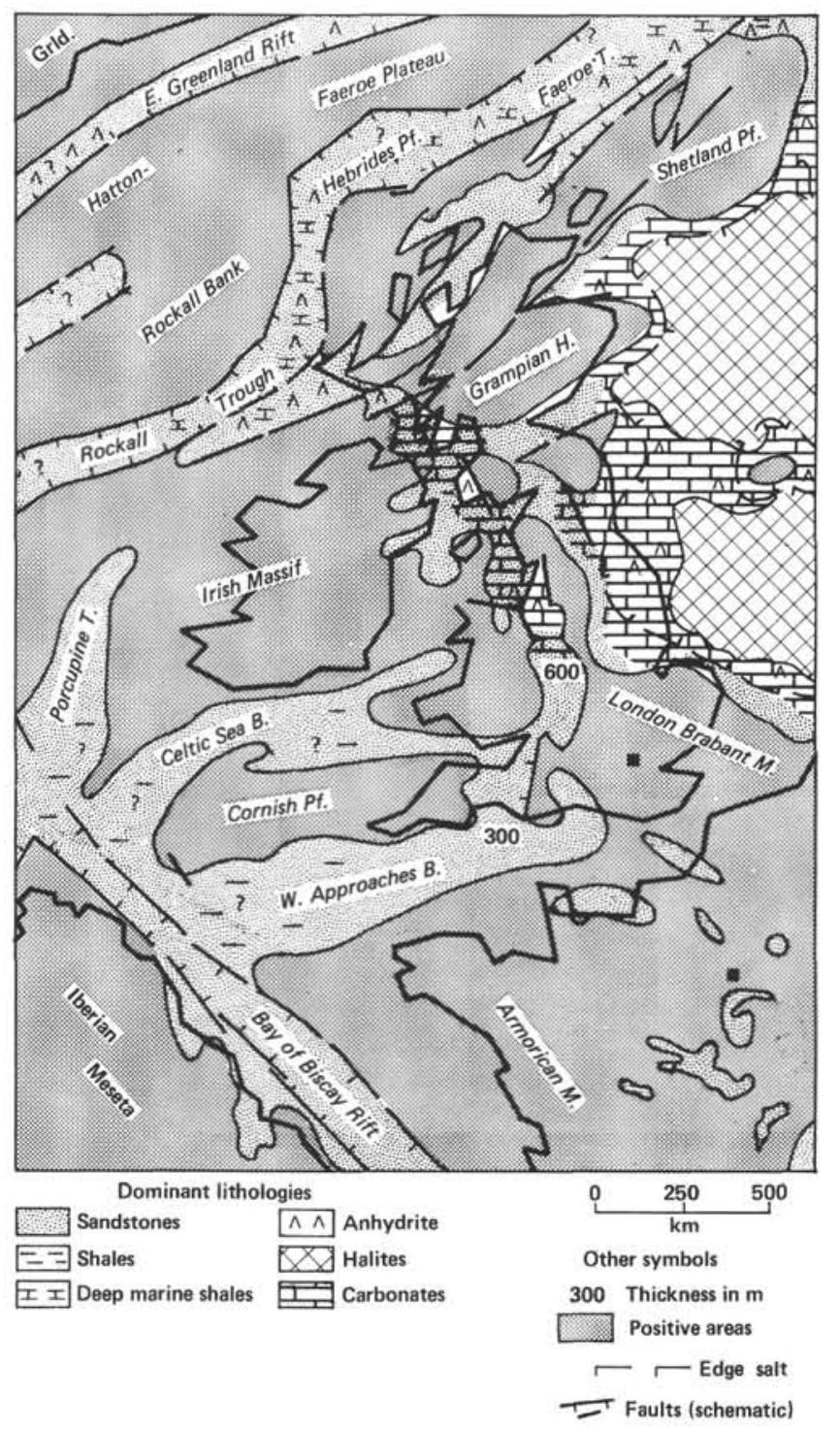

Figure 13. Late Permian geography of northwest Europe (Ziegler, 1981). Compare with Figure 14.

been mapped within the area of Goban Spur by Sibuet et al. (this vol.). These are believed to be reactivated Caledonian fractures (the Goban Fault just north of Pendragon Escarpment is a prominent example).

During rotation, the seaward edges of basement blocks were elevated and subjected to subaerial erosion (documented by coring at Sites 548 and 549 and by seismic profiles; Masson et al., this vol.; Montadert, Roberts, et al., 1979). This process created a system of elongate islands lying parallel to the continental margin in the Early Cretaceous sea. Because Goban Spur was already a structurally high feature, an uplift of a few hundred meters was enough to bring the basement blocks above sea level. In contrast, in the Western Approaches Basin, which was steadily subsiding, asymmetrical basement fault-blocks were submerged too deeply to be eroded. Rifting there was not preceded by regional uplift, and no erosion occurred at the initiation of rifting (Roberts et al., 1981).

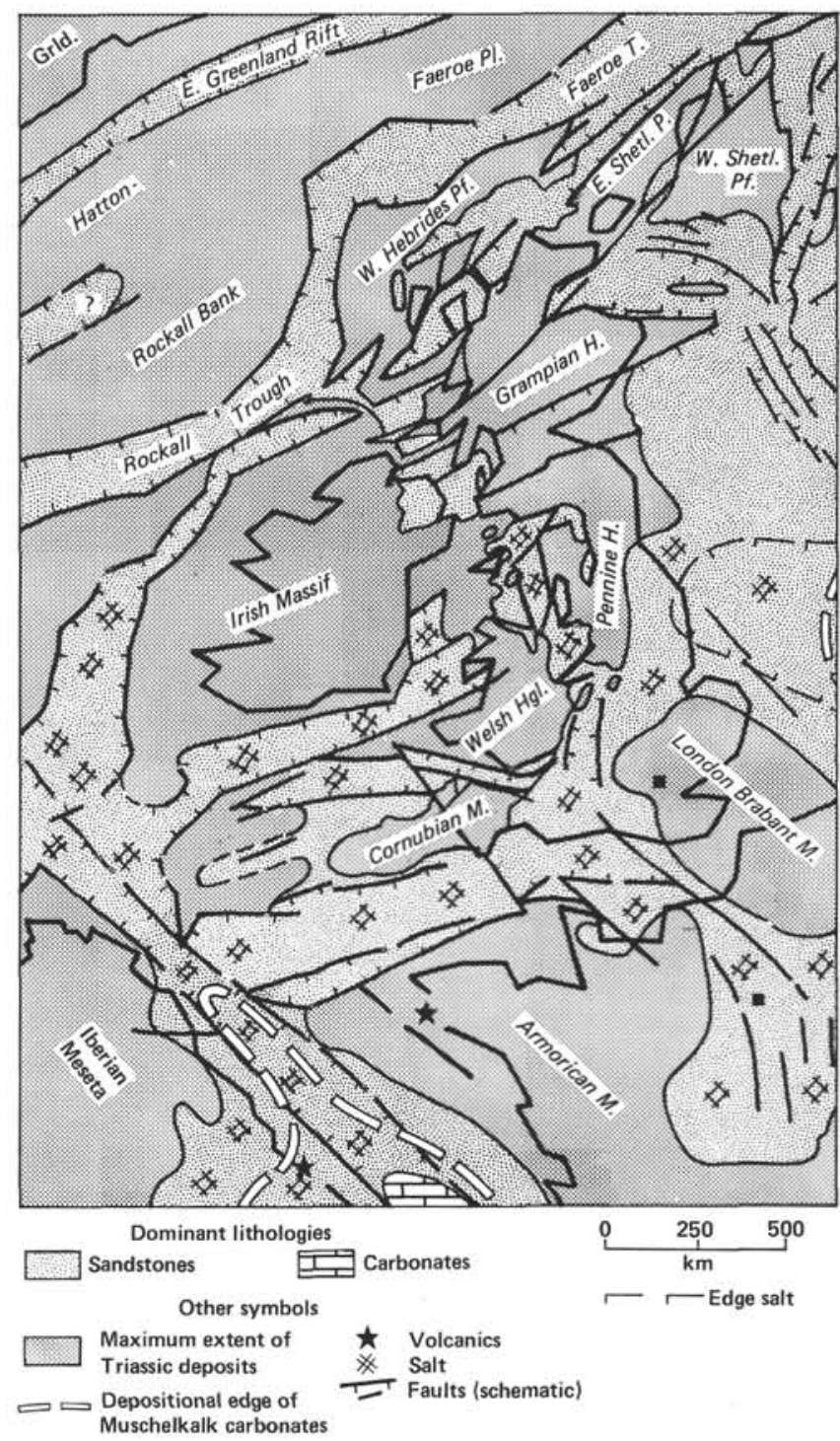

Figure 14. Late Triassic (Keuper) geography of northwest Europe (Ziegler, 1981).

The syn-rift sediments cored on Goban Spur are Barremian and probably Aptian at Site 549. However, late pre-Atlantic rifting took place in the shelf basins to the northwest somewhat earlier during the Jurassic-Cretaceous transition, as the late Cimmerian uplift caused erosion of the Hercynian-Caldonian massifs of Ireland, Cornubia, and Armorica. This erosion was accompanied by deposition of thick disconformable sequences of Wealden continental sands and clays in the Fastnet, Celtic Sea, and Western Approaches basins, and even offshore Eastern Canada (Allen, 1981; Robinson et al., 1981).

Syn-rift formations on the Armorican-Goban Spur region contain few volcanics, but a few Lower Cretaceous basalts have been dredged in Shamrock Canyon (Pastouret et al., 1981). Sibuet et al. (this vol.) divide the phase of rifting into two subphases separated by an Aptian unconformity, which may have formed during a change in tensional movements between the North American and Eurasian domains. Subphase I is dated Late Ju- 


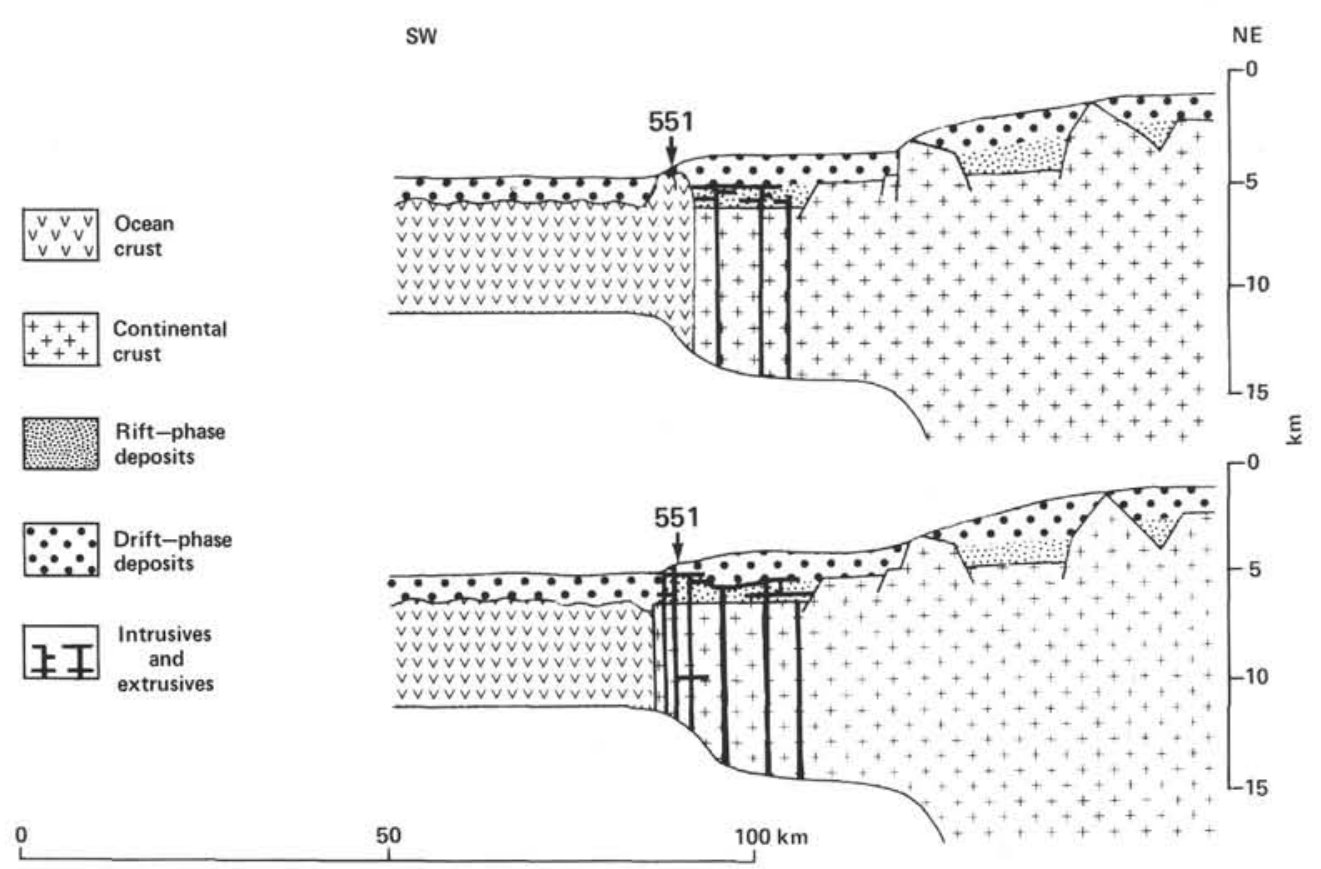

Figure 15. Two geological models for the continent-ocean transition in the region of Site 551 (Masson et al., this vol.).

rassic(?)-early Aptian; shallow-water Barremian layers were deposited in this subphase at Site 549. Subphase II is much shorter, dated as late Aptian to early Albian. It is recorded either by a hiatus (Site 549) or by the deposition of a thick (1000-m) alternating sequence of conglomerates (including fragments reworked from the Hercynian basement) and platform carbonates belonging to the so-called Urgonian facies; both were dredged along Pendragon Escarpment (Pastouret, Masse, et al., 1974). The gradation from lower Albian shallow-water sediments to relatively deep-water (?bathyal) oozes of the middle Albian shows that margin subsidence accelerated toward the end of rifting and the onset of seafloor spreading.

\section{The Opening Atlantic}

Ocean crust west of Goban Spur formed no later than the late Albian, in bathyal to abyssal environments. This means that the basalts are older than 100 m.y. (Hailwood et al., 1980) or 95 m.y. (Kennedy and Odin, 1982). $\mathrm{K}-\mathrm{Ar}$ age determinations were very imprecise owing to late hydrothermal alteration, which mobilized the potash, but the dates obtained are compatible with paleontological data (Maury et al., this vol.). Thus, the North Atlantic opening between the Irish and Canadian margins appears to have postdated the opening of the Bay of Biscay (dated as early Aptian; Montadert, Roberts, de Charpal, et al., 1979). Both openings might be coeval, however, if a triple junction existed in the Bay of Biscay, as proposed by Williams (1975).

This activity also predates complex events that took place in more northern parts of the Atlantic, such as rifting between Greenland and the Rockall Plateau during the Paleocene (Montadert, Roberts, et al., 1979), and the beginning of spreading in the Norwegian Sea in the early Eocene (Talwani et al., 1981). This progressive southto-north opening of the North Atlantic is complicated by a Late Jurassic-Early Cretaceous lifting episode documented in eastern Greenland (Surlyk, 1978).

The presence of lower bathyal or abyssal microfossil and nannofossil assemblages in sediments overlying the basalts of Site 550 supports the geophysical interpretations (Fig. 16), which indicate that the first ocean crust accreted in a water depth of approximately $1800 \mathrm{~m}$ (Masson et al., this vol., Fig. 28). The depth of accretion derived from the theoretical method of Parsons and Sclater (1977) is 1700-1900 m (taking into account sediment loading). This is, however, $800 \mathrm{~m}$ shallower than the depth taken directly from published curves of North Atlantic subsidence (Parsons and Sclater, 1977; Tucholke and Vogt, 1979; Masson et al., this vol.).

The rate of seafloor accretion in this area was low in its early phases. Assuming a late Albian date for the basalts at Site 550 and that the strong magnetic anomaly northwest of the site is Anomaly 34, the rate of accretion was approximately 5 to $9 \mathrm{~mm} /$ yr. (Gruvel, pers. comm., 1982; Scrutton, this vol.). This low figure is compatible with the frequent interbeds of radiolarian- and foraminiferbearing pelagic limestones within the volcanic sequence.

The seaward edge of Goban Spur near Site 551 is marked by escarpments a few hundred meters high, topographically comparable to the basement "outer highs" described by Schuepbach and Vail (1980) as elevations of tectonic origin frequently located near the axes of rifts. Scrutton (this vol.) has shown, however, that gravimetric and magnetic anomalies located at the continent-ocean transition may be caused by the presence of volcanic rocks. Such a view is substantiated by pillow lavas and 


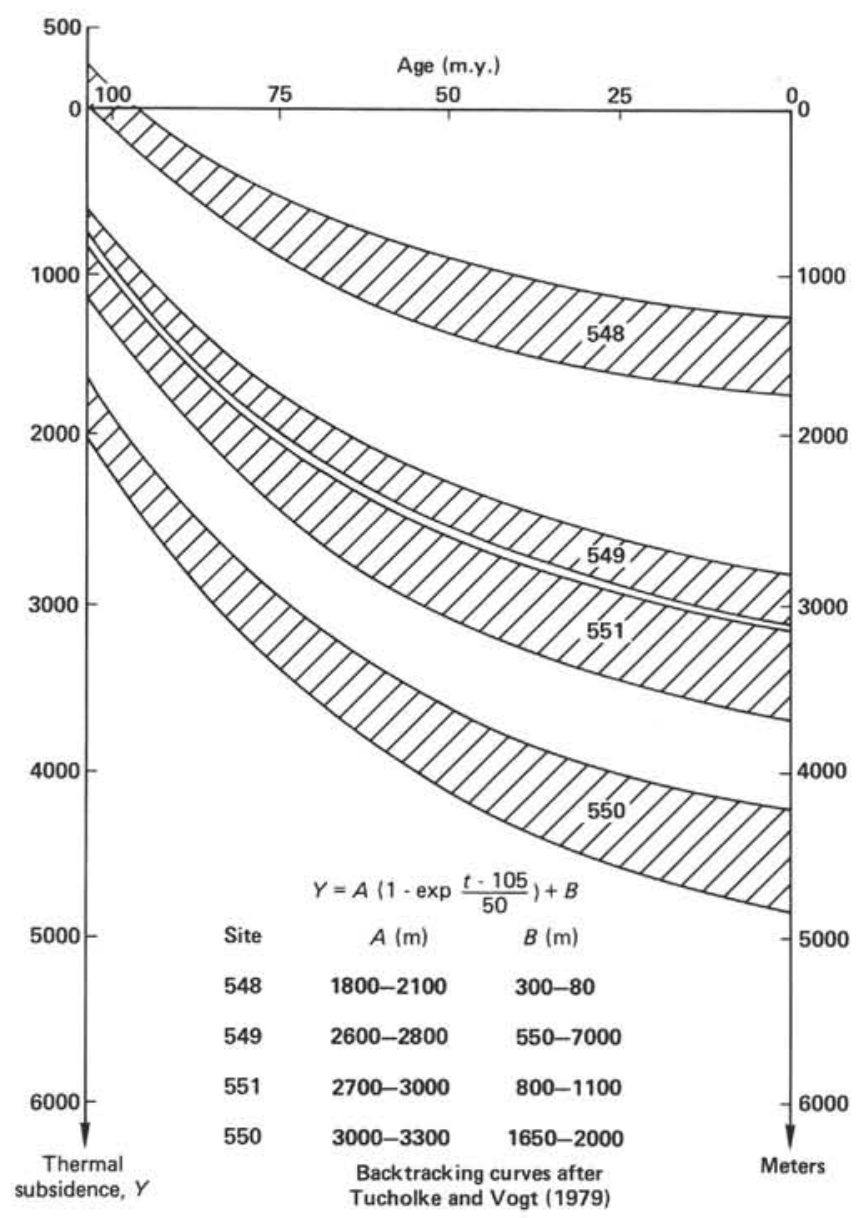

Figure 16. Thermal subsidence curves for Sites 548, 549, 550, and 551 (Masson et al., this vol.).

thin basalt flows drilled at Site 551, which apparently overlie the continental crust and could have been emplaced during rifting. Further substantiation is provided by Lower Cretaceous basalts which have been recently dredged on Goban Spur (Pastouret et al., 1981). The mineralogical and geochemical compositions of basalts from Sites 550 and 551 are very similar to normal oceanic tholeiites; and, in particular, the basalts of Site 551 are clearly different from the continental tholeiites emplaced during pre-rift or early syn-rift volcanism (Maury et al., this vol.). This suggests that the Site 551 basalts could include both intra-rift volcanics and post-rift oceanic lavas. Immediately west of Goban Spur, the continent-ocean boundary appears to follow the unnamed escarpment away from the volcanic ridge beneath Site 551. The boundary is envisioned as a $10-\mathrm{km}$-wide zone of continental crust, extensively intruded and overlain by oceanic basalt. The unnamed escarpment vanishes to the northwest and southeast, however. In addition, along the southern part of Goban Spur, the magnetic anomalies typical of volcanics are missing (Scrutton, this vol.; Fig. 9). Thus, although the concept of a transitional crust formed by continental basement extensively intruded by basaltic oceanic magma is intuitively appealing (Fig. 15), Scrutton (this vol.) has shown that along the southern part of the Goban Spur margin the magnetic and gravimetric data would place the transition zone farther to the west.

A sequential series of subsidence profiles across the Goban Spur margin was combined with the drilling data and geophysical interpretations to produce a series of geologic cross-sections (Gruvel, pers. comm., 1982; Masson et al., this vol.; Fig. 17). Subsidence calculations (Fig. 16) assume the absence of post-rift movement along the listric normal faults. The methods used by Masson et al. (this vol.) to calculate the post-rift subsidence take into account the effects of sediment and seawater loading and subsidence due to cooling of the continental lithosphere since the onset of spreading.

The subsidence history could be determined more accurately if the depositional depth could be precisely determined. Unfortunately, the wide depth-range of deepwater benthic microfossils and the frequent displacement of shallower sediment into deeper water restrict the precision of such determinations at our deepest sites. Nevertheless, we have assembled approximate reconstructions of the depositional and subsidence history of the margin (Fig. 16).

\section{Post-Rift Sedimentation}

The oldest strata above the post-rift unconformity are lower Albian calcareous silty mudstones at Site 549 and upper Albian mudstones at Site 550. This age discrepancy may be explained by the fact that older strata rest in a depression east of Site 550, as inferred from seismic reflection profile CM 10; these older strata can be reasonably assumed to be as old as early Albian. The postrift deposits at Goban Spur can be divided into two parts: (1) pre-Campanian strata whose lithofacies display considerable geographic variability; (2) post-Campanian strata whose lithofacies are geographically more uniform.

\section{Pre-Campanian Strata}

The North Atlantic middle Cretaceous strata are characterized by the widespread distribution of carbonaceous shales. Not surprisingly, we recovered such shales on Goban Spur (Albian and Cenomanian), where they are overlain by or interbedded with white chalks. A variety of lithofacies, a wide range of total organic carbon content, and differences in the origins of the organic matter provide evidence that complex environmental conditions prevailed along the flanks of the narrow Atlantic trough (Figs. 17 and 18).

As seafloor spreading began in the early Albian, pillow basalts poured from the spreading axis (near Site 550 ), gray calcareous mudstones and siltstones accumulated at medium depths on Pendragon Escarpment (Site 549), and the basement high at Site 548 was still subaerially exposed. Recent dredging and diving have revealed Albian very shallow marine deposits (beach rocks) on the Scilly Plateau and in the Western Channel Basin (Pastouret and Pascal, pers. comm., 1983). In the adjacent shelf grabens, such as the Fastnet Basin (Robinson et al., 1981), sands and clays of the "Upper Green Sands" formed a lacustrine, fluvial, coal-bearing deltaic to in- 

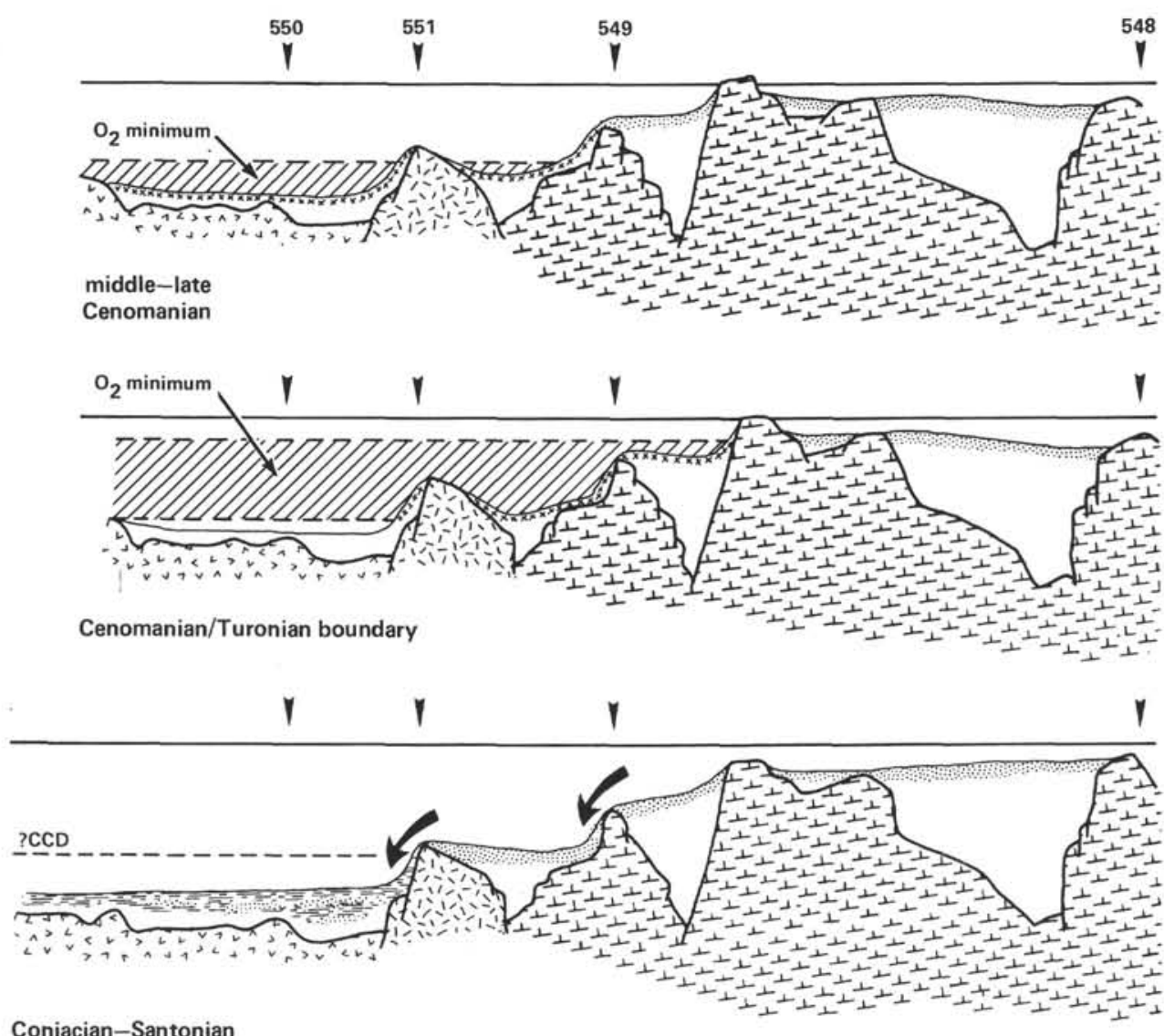

Coniacian-Santonian

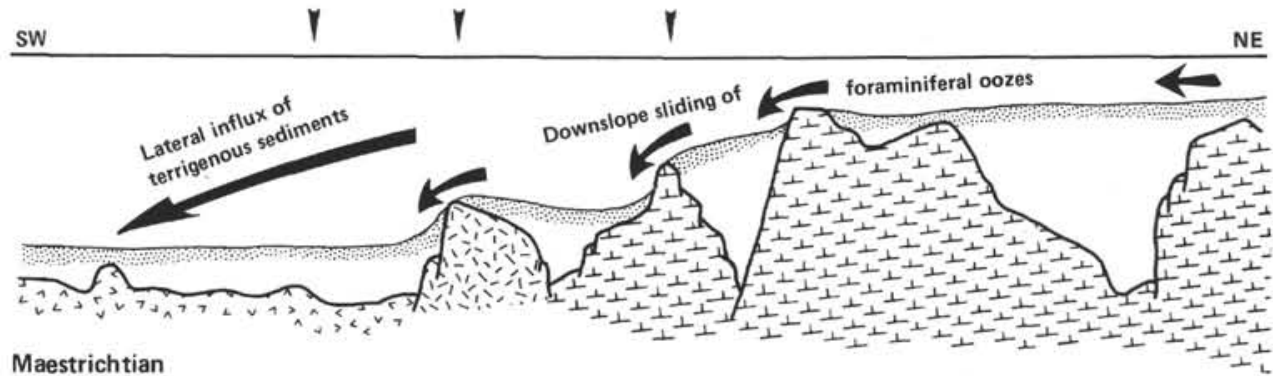

Maestrichtian
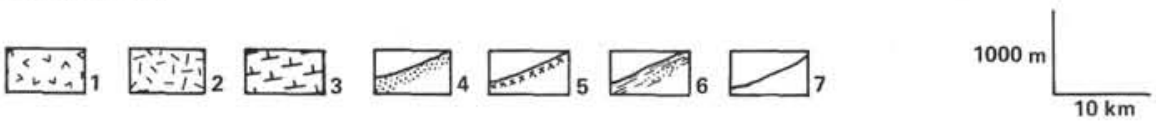

Figure 17. Schematic summary of sedimentary environments at Goban Spur during the Cretaceous. Symbols: 1 = basaltic basement; $2=$ transitional basement; $3=$ Hercynian basement; $4=$ foraminiferal nannofossil chalks; 5 = anoxic sediments; 6 = carbonate-depleted shales with interbedded chalky turbidites; 7 = surface of nondeposition or submarine erosion. (From Gillot, 1983.)

ner sublittoral facies, prograding as Wealden delta-like deposits onto the Jurassic carbonates.

Albian sedimentation at northeastern Atlantic lowerslope sites has been documented at Sites 398 (Sibuet et al., 1980), 400 (Montadert, Roberts, et al., 1979), and 549 (Graciansky and Gillot, this vol.). At Site 549, calcite content in the Albian strata is consistently high. The depositional depth is estimated to have been $1000 \mathrm{~m}$ (Fig. 16). At Site 400 (Meriadzek Terrace), abundant evidence of dissolution suggests proximity to the CCD (Graciansky et al., 1979), and seafloor depth is estimated to have exceeded $2000 \mathrm{~m}$. At Site 398 (Vigo Seamount off
Portugal), where the depositional depth cannot be reliably estimated, deposition took place well below the CCD during most of the Albian (Graciansky and Chenet, 1979). If the concept of a regional CCD is valid for a narrow trough where continental influences dominate, these observations indicate that the aragonite and calcite compensation depths lay between 1000 and $2000 \mathrm{~m}$.

The Albian organic matter at Sites 398, 400, and 549 (pyrolysis) is mainly continental detritus (Deroo, Herbin, et al., 1979; Deroo, Roucaché, et al., 1979; Batten, 1979; Waples and Cunningham, this vol.; Batten, this vol.). The total organic carbon content is modest at 


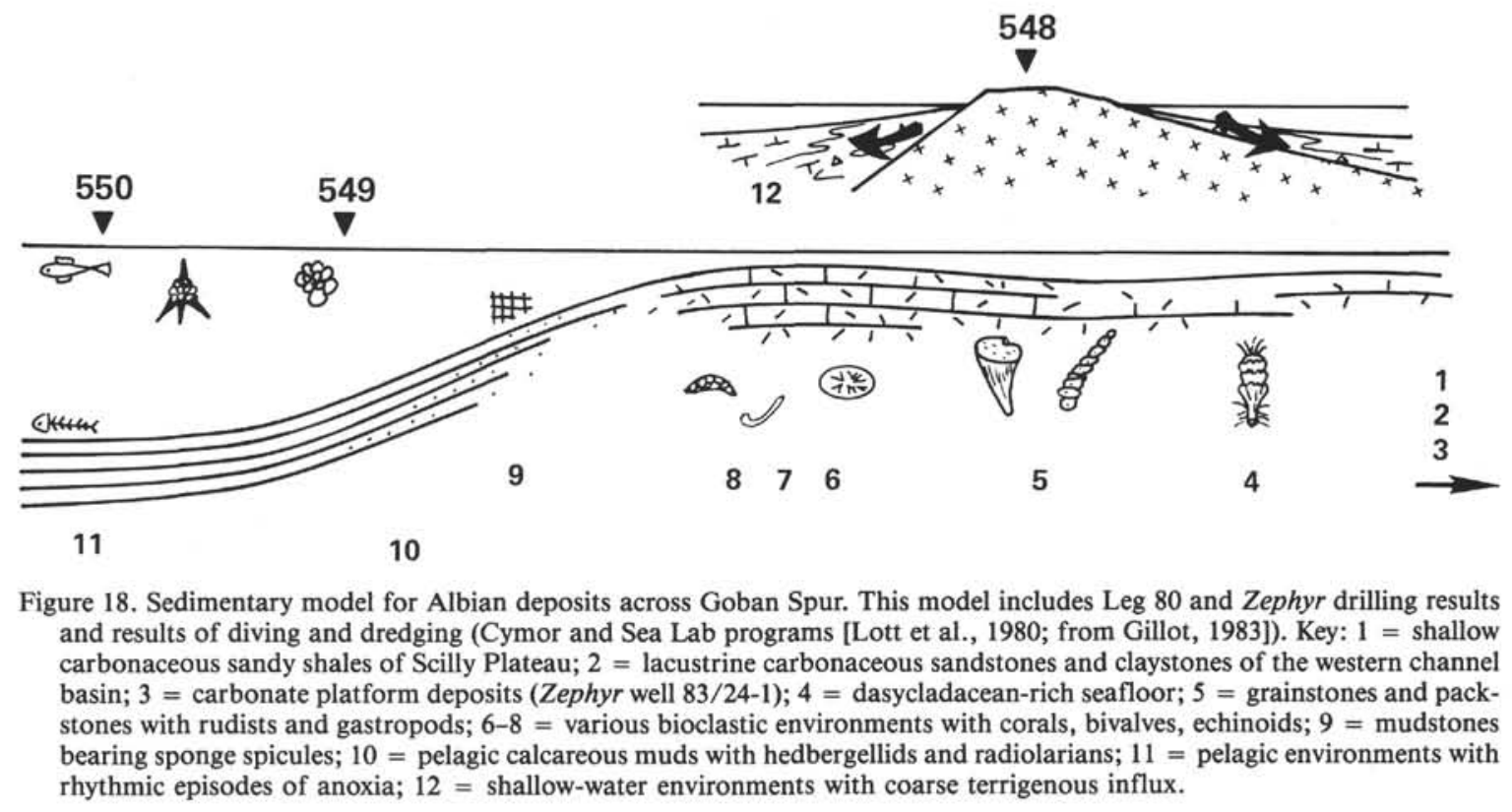

all three sites, in spite of the dark color of the sediments. (Site 400 maximum TOC $=4 \%$; Site 549 TOC $=0.17-$ $1.72 \%$.) The highest TOCs occur in samples containing numerous large wood fragments. The relative resistance of terrestrial plant debris to oxidation and the pervasive bioturbation of the sediments indicate a well-oxygenated seafloor. Such conditions seem to have prevailed on the northwest European, Iberian, and Moroccan margins of the Atlantic. In contrast, predominantly anoxic Albian environments prevailed to the south between the Mid-Atlantic Ridge and the west African margin (Graciansky et al., 1982; Fig. 19).

Cyclic alternations between two main sediment types are characteristic of the North Atlantic black shales (Graciansky et al., 1982). One type is light-colored and lean in organic carbon. The other is dark and also has low organic carbon contents. The average duration of individual cycles is on the order of the duration of astronomic events which affect the earth (Schwarzacher and Fischer, 1982). At Site 400, the origin of the cyclic alternation may have arisen from periodic environmental changes induced by climatic cycles (Mélières, 1979, figs. 2 and 3 ) or from periodic redeposition of shallower calcareous muds within carbonate-depleted deep-water black shales (Graciansky et al., 1979). In fact, the two possibilities are not incompatible, for the two separate processes could have been induced by the same cause. At Site 549 (Graciansky and Gillot, this vol.), the cyclic deposition resulted from a periodic environmental change caused by oceanic turnover, which produced a rhythmic flow of low-energy bottom currents within a very quiet environment.

During the Cenomanian, the "Upper Green Sands" continued to accumulate in the Celtic Sea and Fastnet basins (Robinson et al., 1981), and the Wealden beds were extensively redeposited. Glauconitic white chalks were deposited on the outer Cornubian Platform (Evans et al., 1981), whereas most structural highs were still devoid of sediment (Fig. 17). As the margin continued to subside, pelagic white chalks accumulated in condensed sections at Sites 549 and 551. At the same time, white chalky limestones alternated with dark organic limestones in the narrow, deep trough at the foot of Goban Spur (Site 550). The dark lithologies are comparable in age and facies to Cenomanian black shales recovered at many other DSDP sites of the North Atlantic. The unusual characteristic here is the high calcite content.

The cycles observed in the lower to middle Cenomanian strata at Site 550 and in the Albian strata at Site 549 are comparable (Graciansky and Gillot, this vol.). The main difference is the presence of marine organic matter in the Cenomanian beds (maximum TOC $=2 \%$; Waples and Cunningham, this vol.), which suggests episodic anoxic conditions at the bottom. Of particular interest is that anoxic environments at depositional depths of 2000 to $2500 \mathrm{~m}$ (Site 550; Fig. 16) were contemporaneous with well-aerated environments at $1000 \mathrm{~m}$ (Site 549). This shows that the main part of the water column was well oxygenated, but below a depth of 1800 to $2000 \mathrm{~m}$, periodic stagnation took place.

At sites of intermediate depth on the Goban Spur (549-551), a thin (1-m-thick) upper Cenomanian to lower Turonian black shale is enclosed within white chalks. This black shale has a maximum total organic carbon content of $10 \%$, and the main biogenic component is siliceous. The carbonate content is nearly zero at Site 550 , indicating that the CCD lay between there (reconstructed depositional depth $\sim 1300 \mathrm{~m}$ ) and Site 551 (reconstructed depositional depth $\sim 900 \mathrm{~m}$; Fig. 16; Waples, this vol.), which is remarkably high. Deposition of this particular layer can be correlated with a short carbonaceous episode documented in the North Sea (Plenus Marls, Institute of Geological Science and Norwegian Petroleum Directorate, 1977) and with deposition of the "Black Band" of Yorkshire and Humberside, England (Hart and Bigg, 1981). The discovery of this black shale layer beneath Goban Spur is important because it is the northernmost documentation in the Atlantic of an ap- 


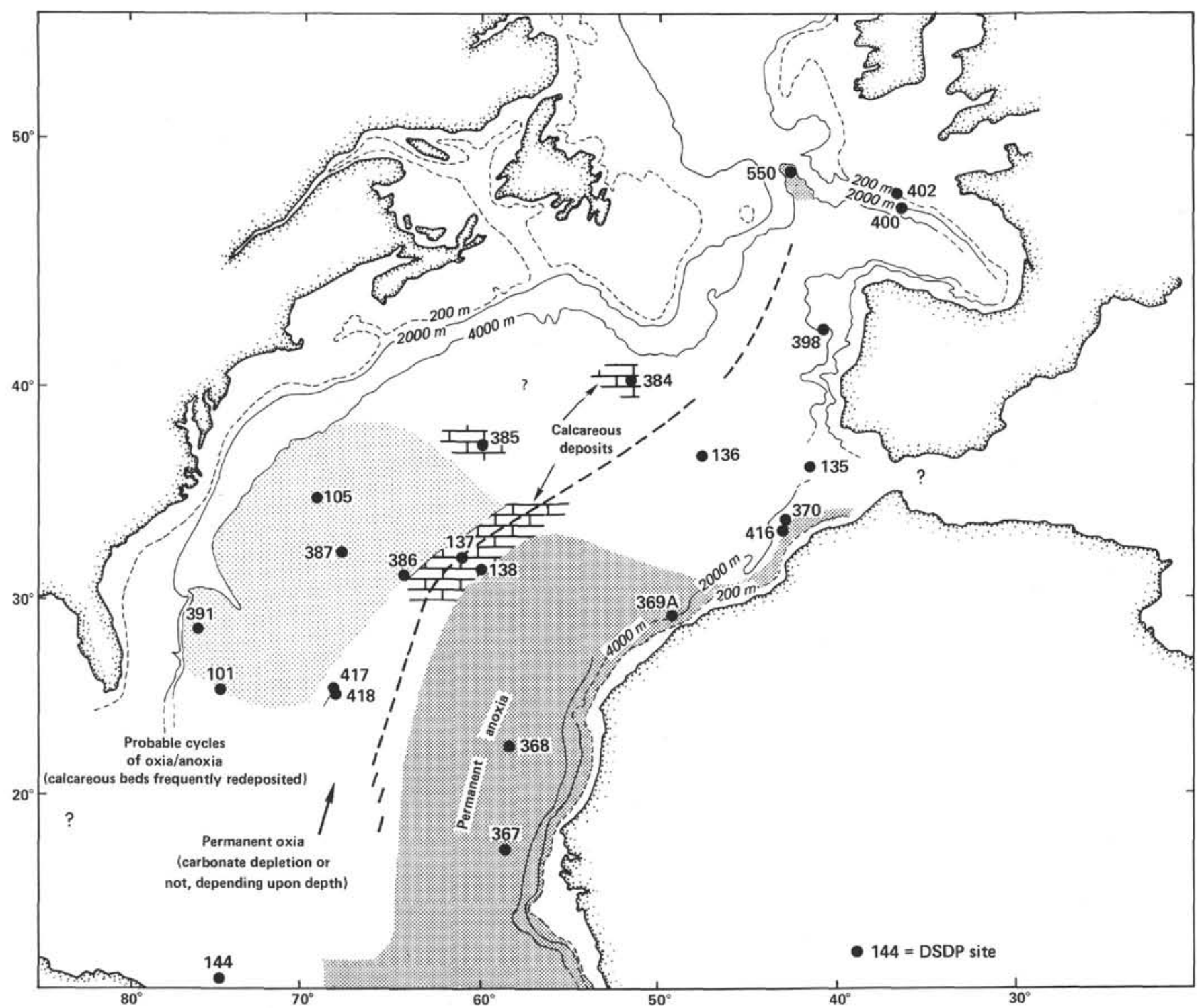

Figure 19. Distribution of depositional environments in the North Atlantic during the Albian-early Cenomanian (from Graciansky, Brosse, et al., in press).

parently oceanwide late Cenomanian-early Turonian anoxic event (Graciansky et al., in press; Fig. 20).

The stratigraphic record of the Cenomanian/Turonian boundary in various regions indicates a general sediment-starvation in the North Atlantic, accompanied by a temporary rise of the CCD. These features can be correlated with an early Turonian highstand of sea level (?450 $m$ higher than present; Hancock and Kauffman, 1979), which was responsible for a wide-scale transgression on the continents. The Late Cretaceous transgression may have fostered marine anoxia (Jenkyns, 1980), but not all major transgressions have induced such events. Calvert (1983) has recently noted the importance of oceanic fertility in understanding the occurrence and distribution of organic-carbon-rich sediments in the past. But there is no simple global model that incorporates all the delicately balanced environmental properties of the ocean.
White chalks increasingly dominated Turonian and early Senonian deposition in the North European epicontinental seas and on the continental slope, as at Site 549. The high topographic positions of Sites 548, 551, 400, 401 , and 402 did not allow preservation of sediment of this age. Beneath Site 550, dark smectitic, abyssal shales interbedded with thin chalky turbidites accumulated during the Santonian and Coniacian. Both lithologies are lean in organic matter, indicating oxygenated bottom waters. Similar conditions were widespread in the North Atlantic during the Senonian (Graciansky et al., 1982). Evidence of strong calcite dissolution within these sediments suggests that the CCD may have been shallower than $3000 \mathrm{~m}$ (Fig. 16).

Such striking lithologic differences between the two Senonian sediment types (biogenic chalks and terrigenous shales) are probably due to calcite dissolution and 


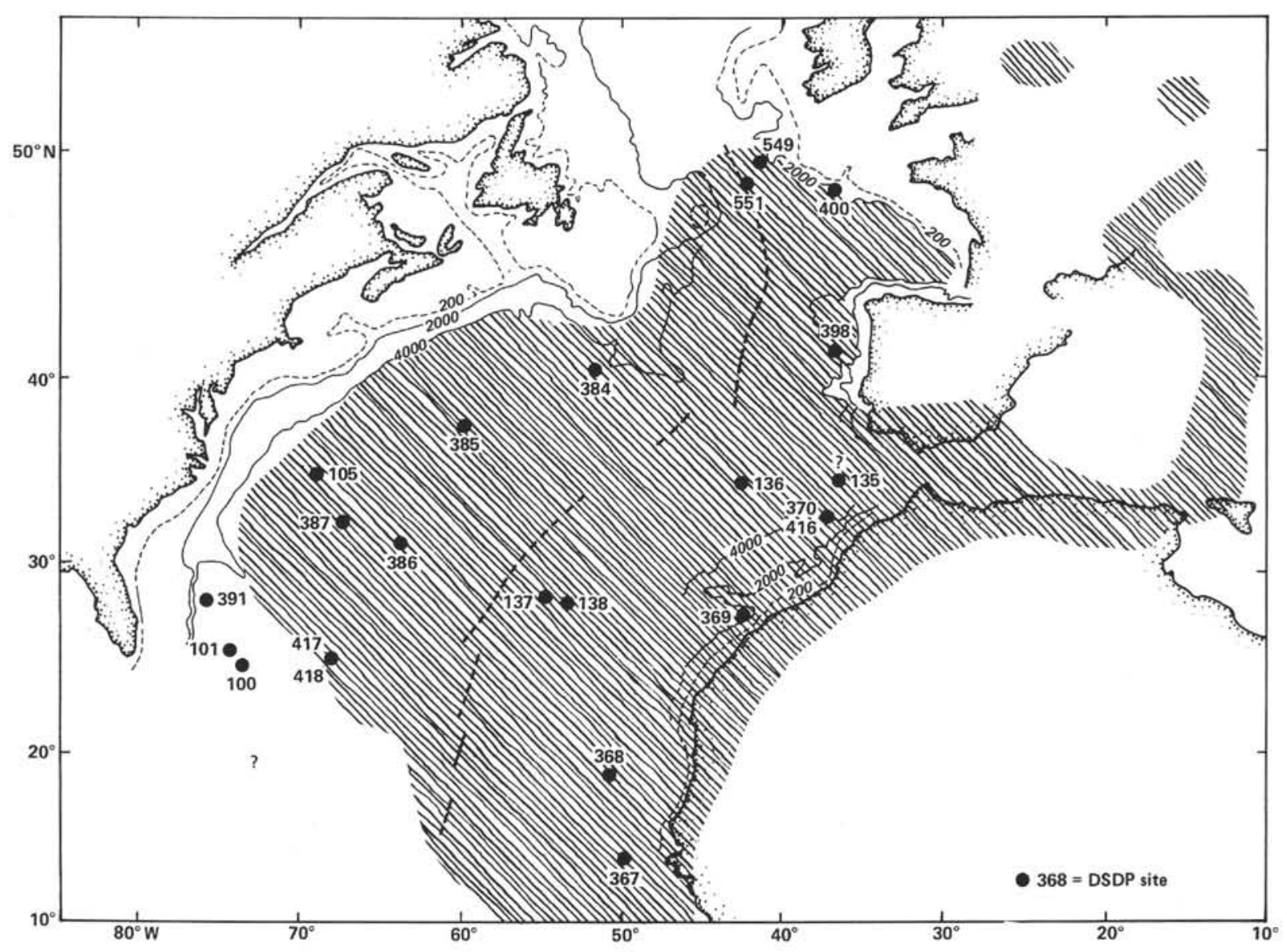

Figure 20. Minimum geographic extent of the Cenomanian-Turonian anoxic layer in the North Atlantic-Tethys region. Water depths in meters (from Graciansky, Deroo, et al., in press).

to different sources and distribution patterns of terrigenous detritus. The increasing dominance of chalky sediments suggests that the individual half-grabens were progressively less isolated from each other owing to the gradual smoothing of seafloor relief by deposition.

\section{Post-Campanian Strata}

Since the late Campanian, chiefly white foraminiferal nannofossil chalks have accumulated at all four Goban Spur sites and widely across the Armorican and Irish continental slopes. The initiation of this chalk-dominant phase is marked by a regional unconformity that separates acoustic Formations (2) and (3) on the Meriadzek margin (Montadert, Roberts, et al., 1979). The unconformity is not clearly visible on the seismic profiles at Goban Spur, but was cored at Sites 548, 549, 550, and 551.

\section{Cretaceous/Tertiary Boundary}

Sediments spanning the Maestrichtian/Danian boundary (which has been the subject of much controversy with regard to the possible occurrence of catastrophic events) are absent from the three shallower sites on Goban Spur. A hiatus (less than 2 m.y. duration) spans the lower Danian at Site 548, most of the Danian (4 m.y.) at Site 549, and the upper Maestrichtian and lower Paleocene (14 m.y. duration) at Site 551 (Snyder et al., this vol.). In the shelf basins (Fastnet, Celtic Sea, Western
Approaches), the Cretaceous/Tertiary boundary is also marked by an unconformity and a sharp change in lithology. At Site 550, however, all the microfossil biostratigraphic zones are represented across the boundary, and preliminary analysis shows an iridium anomaly at the contact (W. Alvarez et al., pers. comm., 1983), in spite of a slight drilling disturbance there.

\section{Late Paleocene-Early Eocene Tectonism, Volcanism, and Deep-Water Oceanic Circulation}

The chalky sedimentation that began in the late Campanian was interrupted during the late Paleocene and early Eocene by brownish chalks enriched in terrigenous clay minerals, biosiliceous components, volcanic debris, and trace quantities of manganese and iron. Similar strata have been cored at widely scattered sites throughout the North Atlantic (Site 119, Laughton, Berggren, et al., 1972; Site 398, Sibuet et al., 1980; Montadert, Roberts, et al., 1979; Evans et al., 1981). The mineralogical composition (Chennaux et al., this vol.), as well as the increased magnetic susceptibility and intensity of remanent magnetism (Townsend, this vol.), reflect the terrigenous influx. In Porcupine Basin, a coeval deltaic platform prograded southward fed by fans from the west and east (Roberts et al., 1981). In the Celtic Sea Basin, a disconformable Cenozoic sequence began with upper Paleocene-lower Eocene fluviatile-detrital deposits interbedded between marine deposits (Naylor and Shannon, 1982). 
An early Cenozoic regional uplift of the Irish landmass (George, 1967) may have been linked with this phase of terrigenous deposition.

Numerous interbedded ash layers contain glass shards, feldspars (sanidines and intermediate plagioclases), and several bentonite beds (Knox, this vol.). The two main ash horizons identified at Site 549 (upper Paleocene and lower Eocene) are of rhyolitic composition. The basal Eocene tuffs at Site 550 have basaltic to andesitic origins. Ashes of similar composition have been found in and around the North Sea (Holland, northern Germany, Denmark, southeastern England) (Fig. 21) (Bøggild, 1918; Jacqué and Thouvenin, 1975) and in the Rockall Bank area (Montadert, Roberts, et al. 1979). They may provide accurate stratigraphic correlations over a wide area (Fig. 22). The Goban Spur ashes may be the distal representatives of a major phase of explosive volcanism that affected the entire northeast Atlantic region during a tensional phase preceding the separation of Greenland from Rockall (Knox and Morton, 1983; Knox, this vol.).

The record of the onset of the tuff-bearing sedimentation is sharp and marked by one or more minor unconformities in the lower Thanetian (for more precise stratigraphic data, see Synder et al., this vol., and Knox, this vol.). At Site 550, the unconformity is marked by a thin layer of manganiferous nodules related to the diagenesis of fecal pellets having high manganese, strontium, and barium contents (Karpoff et al., this vol.). The ash-bearing sequence ends at an unconformity near the middle/upper Eocene boundary (Snyder et al., this vol.). At Site 550, this upper conformity is marked by several superimposed tuffaceous, metalliferous crusts having high $\mathrm{Mn}$ (maximum $\mathrm{Mn}_{3} \mathrm{O}_{4}$ is $7 \%$ ), $\mathrm{Ni}, \mathrm{Co}, \mathrm{Cu}$, and $\mathrm{Ba}$ con- tents. These resemble volcanogenic sedimentary deposits described on the basis of samples from Pacific deep basins and seamounts, where sedimentation rates are low (Karpoff et al., this vol.). The two unconformities that bracket the upper Paleocene-lower Eocene interval are correlative with sea-level drops that produced major erosional unconformities on continental margins (Vail and Hardenbol, 1979).

At Site 548, these two unconformities bound an interval whose magnetic fabric is different from that of all other sediments recovered on Goban Spur (Hailwood and Folami, this vol.). At Sites 548 and 549, the magnetic grain alignment is dominantly downslope, indicating downslope currents. In the lower Eocene, however, the fabric changes from a "downslope" trend to a "crossslope" trend, suggesting the possible influence of contour-current activity derived from the incursion of cold bottom waters into the North Atlantic (perhaps associated with the separation of Greenland and Rockall; Hailwood and Folami, this vol.). This hypothetical change in the oceanic current pattern appears to have had complex effects on the temperature gradients in surface and bottom waters, effects not fully understood. For example, during the late Paleocene hiatus, cooling surface waters caused temperate phytoplankton of the North Atlantic to migrate toward the equator (Haq, 1981). On Goban Spur, surface and bottom waters at Site 548 were cooler before the hiatus than they were after it (Poag et al., this vol.).

A post-cruise survey on Goban Spur has revealed an intraplate compressional phase of deformation during the Eocene (Sibuet et al., this vol.). The new seismic lines display folds and compressional faults dated as Eo-

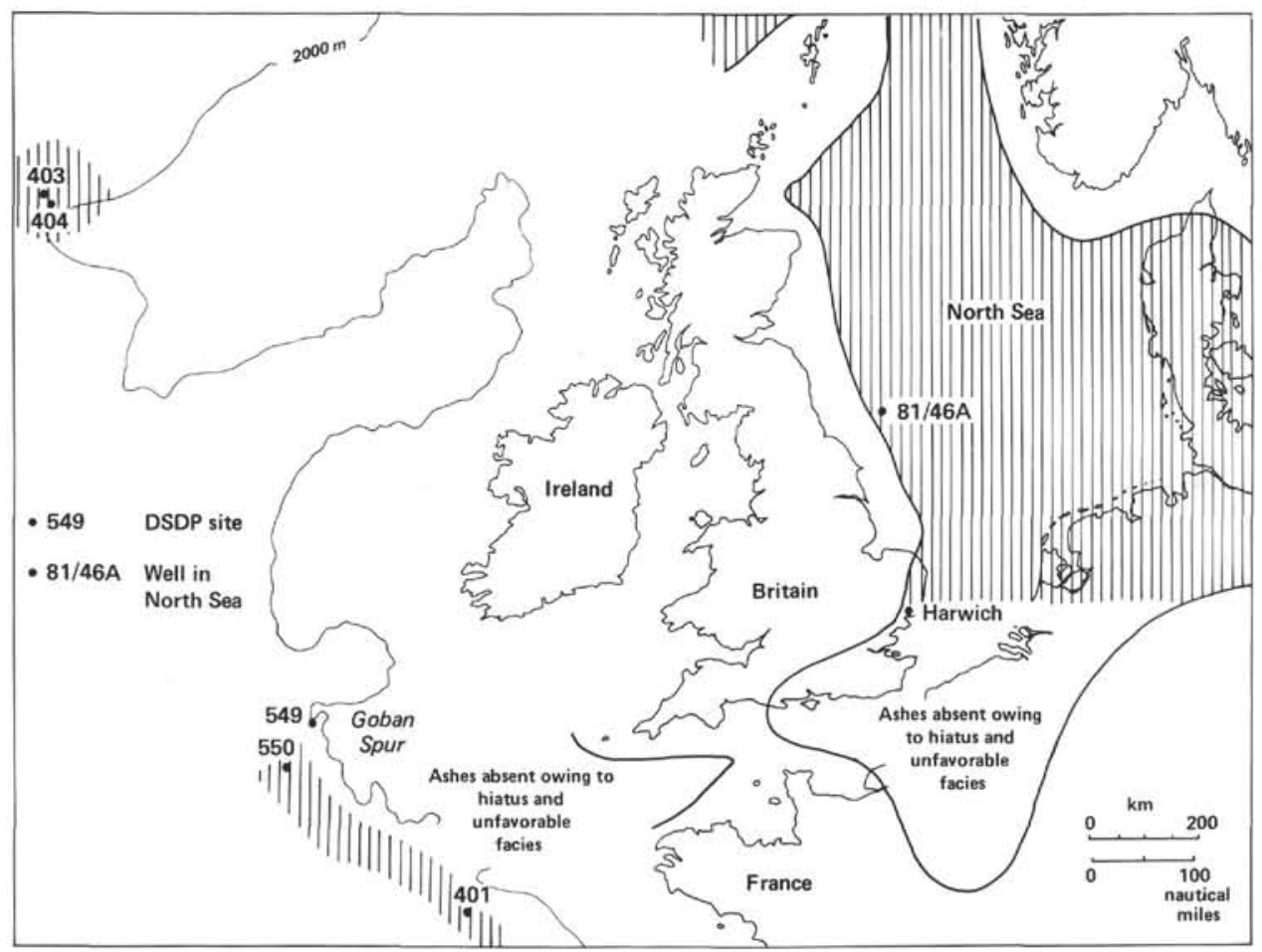

Figure 21. Distribution of early Eocene volcanic ash and bentonites (after Knox, this vol.). 


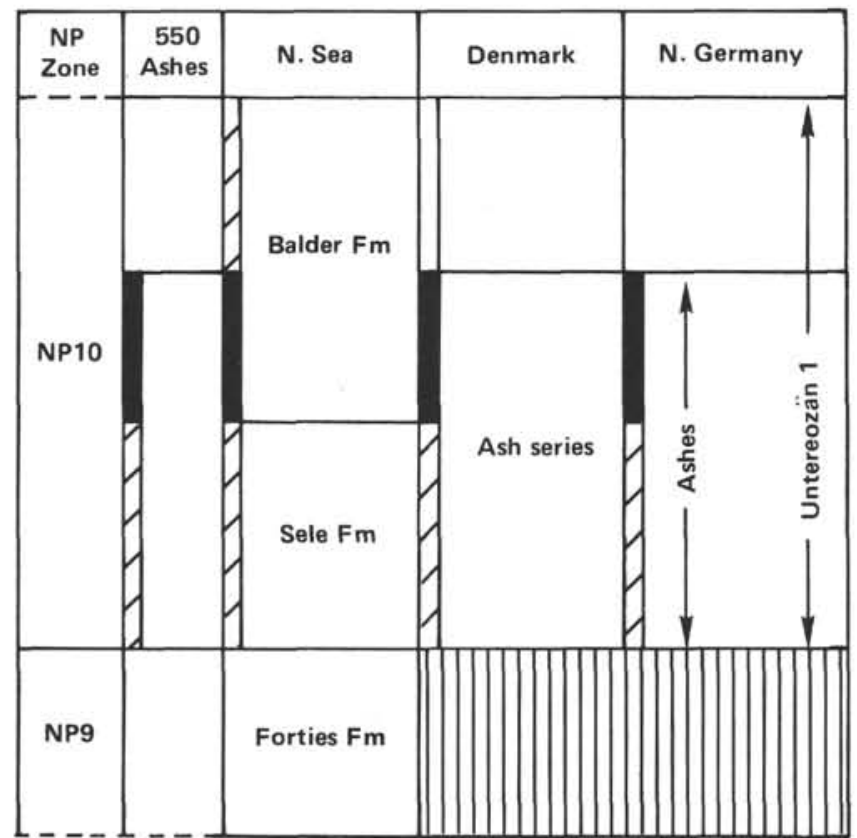

Figure 22. Correlation of early Eocene ash-bearing sequences in the Goban Spur and Biscay Bay areas with those of the North Sea Basin. Narrow hatching, wide hatching, and solid black intervals represent sparse, moderately abundant, and very abundant ash layers, respectively (from Knox, this vol.).

cene, especially near Site 548. Similar Eocene tectonism has been noted on the Trevelyan Escarpment (Montadert, Roberts, et al., 1979). In the adjacent ocean crust, a coherent network of structures reveals north-south compressional trends. These structures include both NW-SE and NE-SW conjugate strike-slip faults and E-W-trending folds and reverse faults. Similar features are known in the Porcupine Sea Bight (Masson and Parson, 1983). Therefore, the western European landmass, as well as large parts of the adjacent ocean crust, seems to have undergone regional compression (oriented roughly northsouth) during the Eocene. This can be related to the Pyrenean orogeny.

The late Paleocene-early Eocene was a particularly active time in North Atlantic history with regard to the number of tectonic and climatic events (Pyrenean tectonism [Masson and Parson, 1983; Sibuet et al., this vol.]; uplift of the Irish landmass and synchronous detrital sedimentation; active rifting in the North Sea and Rockall area; explosive volcanism in northwestern Europe; change in the North Atlantic current pattern; and incursion of North Atlantic cold waters at depth; Fig. 23). All appear to have been consequences of changing patterns and rates of seafloor spreading between Rockall and Greenland (Montadert, Roberts, et al., 1979; Talwani et al., 1981), and all significantly affected deposition on Goban Spur.

By late Eocene time, the northeast Atlantic margin had more or less attained its present water depths and morphology. The Eocene-Oligocene transition was marked by the onset of polar bottom-water production (Berger et al., 1981), recorded by isotopic changes (Kennett and Shackleton, 1976; Vergnaud Grazzini et al.,
1978; Miller et al., this vol.), by a change in the deep-sea benthic fauna (Benson, 1975; Miller et al., this vol.), and by a sharp lowering of the CCD (van Andel and Moore, 1974). This event was coincident with a minor sea-level drop that may have induced erosional unconformities on continental margins (Vail and Hardenbol, 1979). It is also recorded by the strong reflector $R_{4}$ of Roberts (1975), first defined in the Rockall area and now known in the Labrador Sea and Biscay regions. This reflector marks an increased intensity of abyssal circulation (Miller and Tucholke, 1983). Detailed studies of the unusually complete Eocene-Oligocene transition at Site 549 have refined the biostratigraphic resolution of oceanic plankton in this region (Snyder et al., this vol.).

Micropaleontological and isotopic changes in planktonic foraminifers show that ocean surface temperatures dropped suddenly in the early Oligocene. Biogenic productivity was high in the latest Eocene, but fell to a low level in the early Oligocene and progressively increased in the later Oligocene, although temperatures may have remained cool (Loubere, this vol.). This fertility decrease in the early Oligocene, accompanied by the incursion of cool bottom waters, was an unusual event (Berger et al., 1981), and has not yet been clearly explained. A change in benthic foraminiferal abundance 40 to $38 \mathrm{~m}$.y. ago predates the major isotopic change $36.5 \mathrm{~m} . \mathrm{y}$. ago. The decreased bottom-water temperature seems to have been accompanied by an increase in oxygen content, a decrease in carbon dioxide content, and an increase in $\mathrm{pH}$, all recording intensified abyssal circulation in the North Atlantic, associated with the initial entry of bottom water from the Norwegian-Greenland Sea (Miller et al., this vol.).

\section{Upper Oligocene Unconformity}

A major sea-level drop is indicated by Vail and Hardenbol (1979) to have occurred in the late Oligocene, recorded between calcareous nannofossil Zones NP23 and NP24 (Fig. 23). Poag and Schlee (1984) have recognized a coeval regional unconformity on the North American margin. Its eastern counterpart was cored at Sites 548, 549 , and 550, spanning parts of Zones NP23 and 24. Erosional features which cut into the upper Eocene strata are visible downdip from Site 548 on seismic line OC 603. Micropaleontological data indicate that the surface and bottom environments changed at Site 548 just before the hiatus (Poag et al., this vol.). The cause of the general sea-level drop is not thoroughly documented, but Keigwin and Keller (1984) have recently detected an ice-volume signal in the upper Oligocene of the Pacific.

\section{Climatic and Oceanographic Disturbances of the Middle Miocene/Late Miocene}

At Sites 548, 549, and 550, a 6-m.y. hiatus has been recognized between the early middle Miocene and the late Miocene, spanning nannofossil Zones NN7-NN10. Benthic foraminiferal evidence suggests that the environmental conditions (Fig. 23) shifted below the unconformity, perhaps caused by a cooling climate associated with the expansion of the Antarctic ice cap, which grew rapidly during the hiatus (Woodruff et al., 1981; Savin 


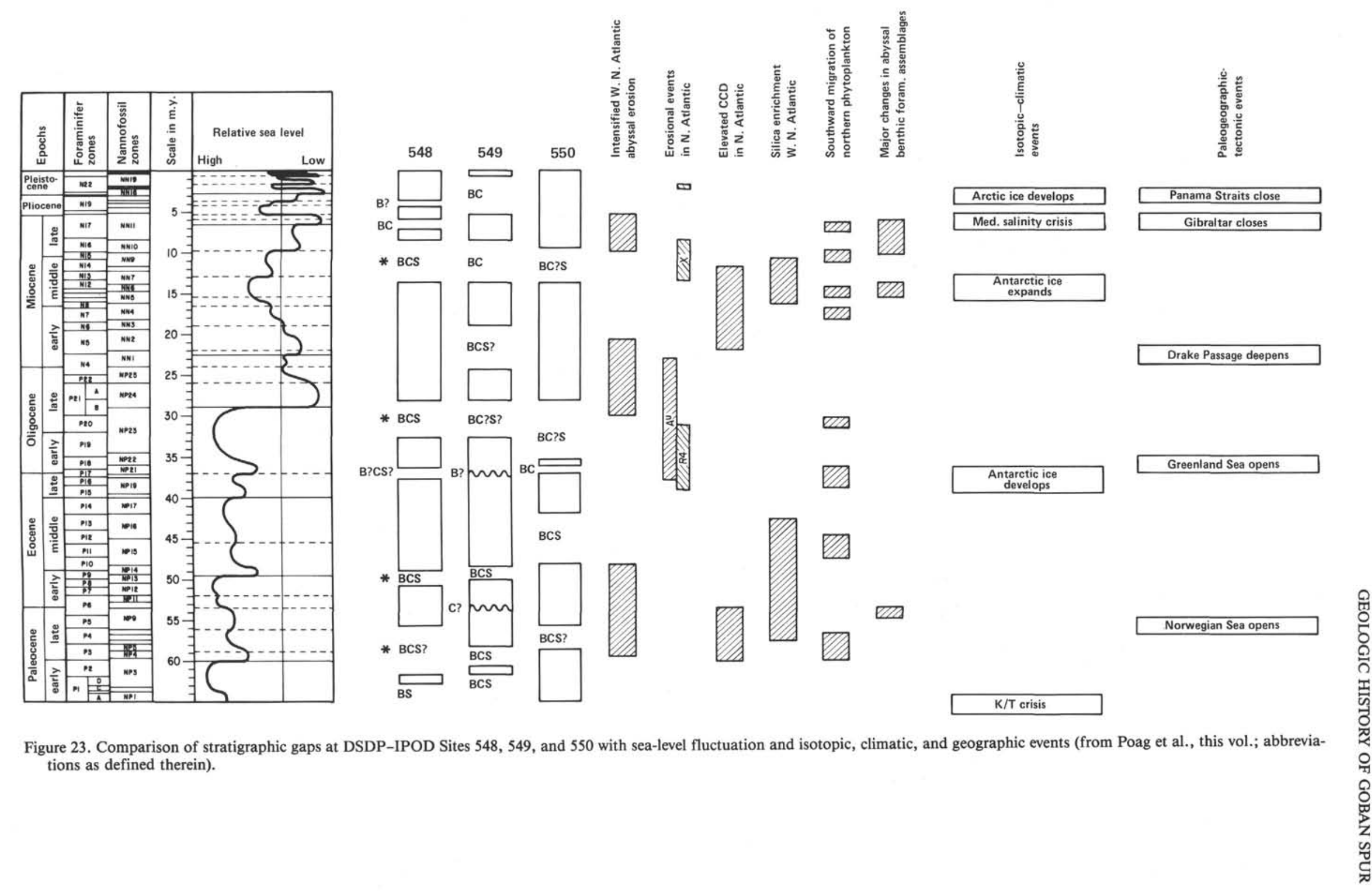


et al., 1975; Berger et al., 1981; Poag et al., this vol.). Significant climatic and oceanographic changes took place during this period throughout the North Atlantic, as evidenced by changes in depositional regime, by an episode of widespread deep-sea erosion (Ruddiman, 1972; Miller and Tucholke, 1983), by a reorganization of deepsea benthic foraminiferal communities (Schnitker, 1979), and by a marked eustatic sea-level drop (Vail and Hardenbol, 1979).

\section{Climatic Events in the Pliocene-Pleistocene}

The unusually complete Pliocene and Quaternary section recovered with the variable-length hydraulic piston corer at Site 548 has yielded a wealth of biostratigraphic paleoclimatic, and paleoceanographic information (Loubere and Jakiel; Harland; Caralp; Pujol and Duprat; Labracherie; and Vergnaud Grazzini and Saliège; all this vol.). The Pliocene/Pleistocene boundary, as identified by study of nannofossils and planktonic foraminifers, lies near the top of the Olduvai paleomagnetic event. But no marked climatological change is associated with this boundary. Glacial-related deposition began in the late Pliocene, as indicated by the initial appearance of ice-rafted pebbles (Chennaux et al., this vol.). Marine deposition in the early and middle Pleistocene was generally uniform, in contrast with significant glacial/interglacial fluctuations in the late Pleistocene (Pujos; Pujol and Duprat; Caralp; Harland; all this vol.). Polar-front displacements caused by glacial ice buildups resulted in increased detrial quartz deposition, sparser and less diverse planktonic assemblages, greater relative abundance of benthic foraminifers, and numerous displaced benthic foraminifers (Shor and Poore, 1979).

\section{Major Unconformities}

Sediment redistribution (erosion) and nondeposition have played important roles in the depositional history of Goban Spur. Their effects can be seen as numerous unconformable reflections on seismic profiles and as biostratigraphic gaps and lithic discontinuities in the cores. In fact, we recovered several significant unconformities in undisturbed condition at each site (Poag et al., this vol.; site chapters, this vol.). The most intensively studied unconformities are those of Site 548 (upper slope), where sharp lithic discontinuities are especially notable (Poag et al., this vol.; Fig. 23). Measurable changes in microfaunal, lithic, and isotopic properties take place across four erosional unconformities at Site 548 (middle Miocene/upper Miocene; lower Oligocene/upper Oligocene; lower Eocene/middle Eocene; lower Paleocene/ upper Paleocene). Environments began to shift before each erosional interval, and sedimentation resumed afterward in the form of turbidites derived from nearly continental slope sources. Coeval unconformities were documented at two other sites (549 on the middle slope, 550 on the abyssal plain), and most are coincident with seismic unconformities. This physical evidence implies episodes of regional and perhaps basin-wide disturbance. Furthermore, comparison with previous compilations of marine hiatuses (Rona, 1973; Vail et al., 1977; Moore et al., 1978; Thiede et al., 1980, 1981; Vail et al.,
1980; Hardenbol et al., 1981; Riggs, 1984; Poag, in press; Poag and Schlee, 1984; Tucholke, 1979, 1981) reveals that major stratigraphic breaks across Goban Spur are identical to those most commonly reported from throughout the North Atlantic basin and its continental margins. Each major hiatus on Goban Spur may be correlated with either a paleoceanographic shift or a sealevel drop, or both (Fig. 23).

Relative sea-level fluctuations appear to have been responsible for most unconformities on the upper slope (e.g., Site 548), but other mechanisms, such as changes in bottom-water circulation or composition and vertical fluctuations of the CCD and water-mass boundaries, appear to have been responsible in part for interrupting deeper-water deposition. Moreover, all these mechanisms may have been linked together by such agents as climatic cycles, regional tectonism, and readjustments of crustal plate positions.

\section{SUMMARY}

The results of a four-site coring transect (Sites 548551) across the continent-ocean boundary at Goban Spur on the Irish continental margin allow a reconstruction of the structural, depositional, and environmental development of this sediment-starved passive margin. Seismic reflection profiles show that, during rifting, continental basement rocks at Goban Spur were broken up by northwest-trending listric normal faults to form a series of half-graben basins. Sites 548 and 549 are on the edge of two of these half-grabens, Site 550 is on the adjacent ocean crust of Porcupine Abyssal Plain, and Site 551 is on transitional crust at the foot of Goban Spur.

At Site 548 (1256 m water depth), Devonian shales and quartzites are part of the subhorizontal, subaerially eroded basement. A phosphatic hardground on this basement is directly overlain by upper Campanian to Holocene foraminiferal chalks and oozes. At Site 549 (2533 m water depth), quartzites resembling the Devonian Old Red Sandstone underlie a 290-m-thick Barremian-Aptian? syn-rift sequence. This sequence begins as hyposaline sandstones and shales, gradually changes to skeletal grainstones, and ends upsection with pelagic foraminiferal silty mudstones. The post-rift sequence comprises chiefly upper Cretaceous to Holocene pelagic chalks, but a significant influx of terrigenous and volcanogenic detritus took place in the Eocene. At Site $550(4432 \mathrm{~m}$ water depth), oceanic tholeiites are overlain by upper Albian-Cenomanian dark gray calcareous, silty mudstones containing both terrestrial and marine organic matter indicative of episodic restricted environments on the seafloor. Coniacian-Santonian shales contain little organic carbon, and are overlain by upper CampanianHolocene foraminiferal and nannofossil oozes. Upper Paleocene-lower Eocene strata are characterized by a high content of biosiliceous matter, numerous interbeds of volcanic ash, and two zones of metalliferous crusts and nodules. At Site 551, oceanic tholeiitic basalts were recovered below an abbreviated Cenomanian-Holocene sequence of white foraminiferal and nannofossil chalks.

The upper Paleozoic-lower Mesozoic structural grain of the northwest European continental margin is reflected by northeast-trending fault systems, which formed a 
series of grabens (Western Approaches, Celtic Sea, and Fastnet basins) and horsts (Goban Spur and Cornubian Platform) that controlled sedimentation patterns during early Mesozoic time. During the mid-Mesozoic, a northwest-trending pattern of listric normal faults developed west of the shelf along the continental slope, eventually leading to opening of the northeastern segment of the Atlantic Ocean. The faults of this later system broke the upper continental crust into rotational blocks, 5 to $20 \mathrm{~km}$ across, which actively influenced deposition during a Late Jurassic-Early Cretaceous phase of stretching and rifting. Gravimetric and magnetic data help to define the boundaries between the continental, transitional, and ocean crusts west of Pendragon Escarpment, but several uncertainties remain.

The geologic history of the northeastern Atlantic margin at Goban Spur and vicinity can be divided into three main phases:

1. Early distension in the Caledonian-Hercynian shield produced a complex pattern of conjugate shear faults during late Stephanian to Autunian time. A second phase of regional shearing and extension took place in the Permian-Triassic interval, initiating the northeast-trending sedimentary basins of the northwest Europe shelf, and also the northwest-trending Bay of Biscay Rift.

2. The Goban Spur rift system, which produced northwest-trending listric normal faults in the upper continental crust, consists of rotational blocks that bound half-grabens filled with Lower Cretaceous synrift sedimentary wedges. The main fault trend may be in part a reactivation of a Permo-Triassic strike-slip fault system that extended from the Bay of Biscay to western Greenland. Goban Spur rifting probably began during the late "Cimmerian" phase of regional emergence (Late Jurassic). The chiefly Barremian syn-rift deposits drilled at Site 549 show a clear transgressive sequence from hyposaline to pelagic sediments. Seismic-sequence analysis suggests that elsewhere on the Goban Spur thick Aptian strata also are part of the syn-rift sequence.

3. The post-rift phase began with the slow accretion $(0.5 \mathrm{~cm} / \mathrm{yr}$.) of typical oceanic tholeiites west of Goban Spur (e.g., Site 550), in lower bathyal to abyssal environments (estimated water depth $\sim 1800 \mathrm{~m}$ ) during the Albian. Oldest post-rift sediments documented are lower Albian (Site 549). The "basement outer high" beneath Site 551 appears to have formed by intrusion of oceanic tholeiites into the edge of continental crust during the late stages of rifting. The post-rift deposition west of Goban Spur thus began later (early Albian) than in the Bay of Biscay (early Aptian).

During the early stages of post-rift deposition (Albian-Santonian), local environmental conditions varied considerably across Goban Spur because the half-grabens were still partly isolated from each other by the rugged seafloor topography. Black shales with variable organic carbon and calcite contents were deposited in deepest areas, reflecting occasional pulses of anoxia and carbonate depletion. During the early Albian, some elevated areas were blanketed by shallow bioclastic deposits, such as beach rocks.
During the Cenomanian, white chalks blanketed the higher parts of the slope and the outer shelf rather uniformly, whereas glauconitic sand accumulated in the Celtic Sea and Fastnet basins. However, a drastic environmental change took place at the Cenomanian-Turonian transition as bottom waters stagnated.

During the Campanian, the half-grabens of Goban Spur were filled, smoothing the seafloor relief. Rapid production of biogenic carbonate, accompanied by widespread sediment redistribution, spread a relatively uniform pelagic blanket across the continental slope and abyssal plain.

During the late Paleocene-early Eocene, a marked uplift of the Irish landmass supplied abundant terrigenous debris to Goban Spur. Simultaneously, explosive volcanic activity in the vicinity of Rockall and the North Sea brought several widespread ash layers to the region. This early Paleogene interval was bracketed between two periods of slow deposition that are marked at the deepest site (550) by metalliferous crusts and nodules.

Post-Eocene deposition was greatly influenced by regional or basin-wide climatic and oceanographic events. For example, the Eocene-Oligocene transition coincided with the onset of polar bottom-water production. In the early late Oligocene, widespread North Atlantic abyssalto-shelf erosion created a significant unconformity. A global climatic and oceanographic disturbance between the middle and late Miocene appears to have been related to rapid growth of an Antarctic ice cap. Upper Pliocene and Quaternary deposits are characterized by alternating calcareous and marly calcareous oozes and by shelf microfaunas displaced as sea level rose and fell from interglacial to glacial.

Nearly all the major unconformities documented at Goban Spur can be correlated with eustatic sea-level falls recorded at other widespread locations in the North Atlantic basin and on surrounding continental shelves. Several can be correlated with regional tectonic movements or climatic or oceanographic events, such as shifts in deep circulation patterns and CCD. All these mechanisms appear to have been linked together by complex and delicately balanced interrelationships that have yet to be fully understood.

\section{ACKNOWLEDGMENTS}

We are deeply indebted to all those researchers who contributed directly or indirectly to this volume. They have significantly advanced our knowledge of the geologic development of Goban Spur and vicinity, and this summary chapter is possible only as a result of their determined efforts. We thank D. G. Roberts and J. C. Sibuet for critical reviews of the original manuscript, D. G. Masson for several important suggestions, and André Pascal for providing unpublished results from the Cymor program of submersibles research.

\section{REFERENCES}

Allen, P., 1981. Pursuit of Wealden models. J. Geol. Soc. London, 138:375-405.

Arthaud, F., and Matte, P., 1975. Les décrochements tardi-hercyniens du Sud-ouest de l'Europe; géométrie et essai de reconstitution des conditions de la déformation. Tectonophysics, 25:139-171.

Auffret, G. A., Pastouret, L., Cassat, G., de Charpal, O., Cravatte, J., and Guennoc, P., 1979. Dredged rocks from the Armorican and Celtic margins. In Montadert, L., Roberts, D. G., et al., Init. 
Repts. DSDP, 48: Washington (U.S. Govt. Printing Office), 995-1013.

Avedik, F., 1975. The seismic structure of the Western Approaches and the South Armorican continental shelf and its geological interpretation. In Woodland, A. W. (Ed.), Petroleum and the Continental Shelf of North West Europe. 1, Geology: London (Applied Science Publishers), pp. 29-43.

Avedik, F., and Howard, D., 1979. Preliminary results of a seismic refraction study in the Meriadzek-Trevelyan area, Bay of Biscay. In Montadert, L., Roberts, D. G., et. al., Init. Repts. DSDP, 48: Washington (U.S. Govt. Printing Office), 1015-1023.

Ballý, A. W., Bernoulli, D., David, G. A., and Montadert, L., 1981. Listric normal faults. Proc. 26th Internat. Geol. Congr., Oceanol. Acta Suppl., 4:87-101.

Batten, D. J., 1979. Miospores and other acid-resistant microfossils from the Aptian/Albian of Holes 400A and 402A, DSDP-IPOD Leg 48, Bay of Biscay. In Montadert, L., Roberts, D. G., et al., Init. Repts. DSDP, 48: Washington (U.S. Govt. Printing Office), 379-588.

Benson, M. L., 1975. The origin of the psychrosphere as recorded in changes of deep-sea ostracode assemblages. Lethaia, 8:69-83.

Berger, W. H., Vincent, E., and Thierstein, H. R., 1981. The deep-sea record: major steps in Cenozoic ocean evolution. In Warme, J. E., Douglas, R. G., and Winterer, E. L. (Eds.), The Deep Sea Drilling Project: $A$ Decade of Progress. Soc. Econ. Paleontol. Mineral. Spec. Publ., 32:489-504.

Bøggild, O. B., 1918. Den vulkanske Aske i Moleret samt en Oversigt over Danmarks aeldre Tertiaerbjaergarter. Danm. Geol. Unders. Raekke 2, 33:1-159.

Calvert, S. E., in press. Oceanographic controls on the accumulation of organic matter in the ocean. In Brooks, J., and Fleet, A. J. (Eds.), Marine Petroleum Source Rocks: Oxford (Blackwells).

Colin, J. P., Lehman, R. A., and Morgan, B. E., 1981. Cretaceous and Late Jurassic biostratigraphy of the north Celtic Sea Basin, offshore of southern Ireland. In Neale, J. W., and Brasier, M. D. (Eds.), Microfossils from Recent and Fossil Shelf Seas: Chichester (Ellis Horwood Ltd.), pp. 122-155.

de Charpal, O., Guennoc, P., Montadert, L., and Roberts, D. G., 1978. Rifting, crustal attenuation, and subsidence in the Bay of Biscay. Nature, 275:706-711.

Deroo, G., Herbin, J. P., Roucaché, J., and Tissot, B., 1979. Organic geochemistry of Cretaceous mudstones and marly limestones from DSDP Sites 400 and 402, Leg 48, eastern North Atlantic. In Montadert, L., Roberts, D. G., et al., Init. Repts. DSDP, 48: Washington (U.S. Govt. Printing Office), 921-930.

Deroo, G., Roucaché, J., and Tissot, B., 1979. Organic geochemistry of Cretaceous shales from DSDP Site 398, Leg 47B, eastern North Atlantic. In Sibuet, J.-C., Ryan, W. B. F., et al., Init. Repts. DSDP, 47, Pt. 2: Washington (U.S. Govt. Printing Office), 513-521.

Dingle, R. V., and Scrutton, R. A., 1977. Continental margin fault pattern mapped southwest of Ireland. Nature, 268:720-723.

Evans, C. D. R., Lott, G. K., and Warrington, G. (compilers), 1981. The Zephyr (1977) wells, South-Western Approaches and western English Channel. Inst. Geol. Sci., 81(1).

George, T. N., 1967. Landform and structure in Ulster Scott. J. Geol., $3: 413-448$.

Gillot, E., 1983. La marge celtique au Crétacé d'aprés le campagne 80 du DSDP-IPOD (Atlantique NE) [Thèse]. Univ. Dijon.

Graciansky, P. C. de, Auffret, G. A., Dupeuble, P., Montadert, L., and Miller, C., 1979. Interpretation of depositional environments of the Aptian/Albian black shales on the north margin of the Bay of Biscay (DSDP Sites 400 and 402). In Montadert, L., Roberts, D. G., et al., Init. Repts. DSDP, 48: Washington (U.S. Govt. Printing Office), 877-907.

Graciansky, P. C. de, Brosse, E., Deroo, G., Herbin, J. P., Montadert, L., Müller, C., Sigal, J., and Schaaf, A., 1982. Les formations d'âge Crétacé de l'Atlantique Nord et leur matiere organique. Rev. Inst. Fr. Pet., 37:275-337.

in press. Organic-rich sediments and paleoenvironmental reconstructions of the Cretaceous North Atlantic. In Fleet, A. (Ed.), Marine Petroleum Source Rocks, Spec. Publ. Geol. Soc. London.

Graciansky, P. C. de, and Chenet, P. Y., 1979. Sedimentological study of Cores 138-56, upper Hauterivian to lower Cenomanian, an at- tempt at reconstruction of paleoenvironments, Site 398. In Sibuet, J. C., Ryan, W. B. F., et al., Init. Repts. DSDP, 47, Pt. 2: Washington (U.S. Govt. Printing Office), 403-418.

Graciansky, P. C. de, Deroo, G., Herbin, J. P., Montadert, L., Müller, C., Schaaf, A., and Sigal, J., in press. Ocean-wide stagnation episode in the Upper Cretaceous. Nature.

Guennoc, P., Jonquet, H., and Sibuet, J. C., 1978. Carte magnétique de l'Atlantique nord-est. Published by CNEXO, Brest.

Hailwood, E. A., Hamilton, N., and Morgan, G. E., 1980. Magnetic polarity dating of tectonic events at passive continental margins. Philos. Trans. R. Soc. London, Ser. A., 294:189-208.

Hancock, J. M., and Kauffman, E. G., 1979. The great transgressions of the Late Cretaceous. J. Geol. Soc. London, 136:175-186.

Haq, B. U., 1981. Paleogene paleoceanography: early Cenozoic oceans revisited: Proc. 26th Internat. Geol. Congr., Oceanol. Acta Suppl., 4:71-82.

Hardenbol, J., Vail, P. R., and Ferrer, J., 1981. Interpreting paleoenvironments, subsidence history, and sea-level changes of passive margins from seismic and biostratigraphy. Proc. 26th Internat. Geol. Congr. Oceanol. Acta Suppl., 4:33-44.

Hart, M. B., and Bigg, P. J., 1981. Anoxic events in the Late Cretaceous chalk seas of northwest Europe. Internat. Geol. Correl. Prog., Project 58, pp. 177-185.

Institute of Geological Science and Norwegian Petroleum Directorate, 1977. A Standard Lithostratigraphic Nomenclature for the Central and Northern North Sea. Report 77-25.

Jacqué, M., and Thouvenin, J., 1975. Lower Tertiary tuffs and volcanic activity in the North Sea. In Woodland, A. W. (Ed.), Petroleum and the Continental Shelf of North West Europe. 2, Geology: London Applied Science Publishers), pp. 455-465.

Jenkyns, H. C., 1980. Cretaceous anoxic events: from continents to oceans. J. Geol. Soc. London, 137:171-188.

Kay, M., 1969. Continental drift in North Atlantic Ocean, North Atlantic geology and continental drift. Mem. Am. Assoc. Petrol. Geol., 12:965-973.

Keigwin, L. D., and Keller, G., 1984. Middle Oligocene climatic change from equatorial Pacific Site 77. Geology, 12:16-19.

Kennedy, W. J., and Odin, G. S., 1982. The Jurassic and Cretaceous time-scale in 1981. In Odin, G. S. (Ed.), Numerical Dating in Stratigraphy (2 vols.): Chichester (John Wiley and Sons).

Kennett, J. P., and Shackleton, N. J., 1976. Oxygen isotopic evidence for the development of the psychrosphere 38 m.y. ago. Nature, 260:512-515.

Knox, R. W., and Morton, A. C., 1983. Stratigraphical distribution of early paleopyroclastic deposits in the North Sea Basin. Proc. Yorkshire Geol. Soc., 44:355-363.

Kristoffersen, Y., 1978. Sea-floor spreading and the early opening of the North Atlantic. Earth Planet. Sci. Lett., 38:273-290.

Laughton, A. S., Berggren, W. A., et al., 1972. Init. Repts. DSDP, 12: Washington (U.S. Govt. Printing Office).

Lefort, J. P., 1973. La zonale Biscay-Labrador: mise en évidence de cisaillements dextres antérieurs à l'ouverture de l'Atlantique Nord. Mar. Geol., 14:M33-M38.

Leutwein, F., Sonet, J., and Zimmerman, J. L., 1972. Dykes basiques du Massif Armoricain septentrional. Compt. Rend. Acad. Sci. Paris, 275:1327-1330.

Lott, G. K., Knox, R. W., Bigg, P. J., Davey, R. J., and Morton, R. C., 1980. Aptian-Cenomanian stratigraphy in bore holes from offshore south-west England. Rep. Inst. Geol. Sci., 80(8):1-12.

Masson, D. G., and Parson, L. M., 1983. Eocene deformation on the continental margin SW of the British Isles. J. Geol. Soc. London, 140(6):913-920.

Masson, D. G., and Roberts, D. G., 1981. Late Jurassic-Early Cretaceous reef trends on the continental margin southwest of the British Isles. J. Geol. Soc. London, 138:437-443.

Max, M. D., 1978. Tectonic control of offshore sedimentary basins to the north and west of Ireland. J. Petrol. Geol., 1(1):103-110.

Mélières, F., 1979. Mineralogy and geochemistry of selected Albian sediments from the Bay of Biscay, Deep Sea Drilling Project, Leg 48. In Montadert, L., Roberts, D. G., et al., Init. Repts. DSDP, 48: Washington (U.S. Govt. Printing Office), 855-876.

Miller, K. G., and Tucholke, B. E., 1983. Development of Cenozoic abyssal circulation south of the Greenland-Scotland Ridge. In Bott, M., Saxov, S., Talwani, M., and Thiede, J. (Eds.), Structure and 
Development of the Greenland-Scotland Ridge: New York (Plenum Press), pp. 549-589.

Montadert, L., de Charpal, O., Roberts, D. G., Guennoc, P., and Sibuet, J. C., 1979. Northeast Atlantic continental margins: rifting and subsidence processes. In Talwani, M., Hay, W. W., and Ryan, W. B. F. (Eds.), Deep Drilling Results in the Atlantic Ocean: Continental Margins and Paleoenvironments: Washington (American Geophysical Union), pp. 154-186.

Montadert, L., Roberts, D. G., et al., 1979. Init. Repts. DSDP, 48: Washington (U.S. Govt. Printing Office)

Montadert, L., Roberts, D. G., Auffret, G. A., Bock, W. O., Dupeuble, P. A., et al., 1977. Rifting and subsidence on northeast Atlantic passive margins. Nature, 277:305-309.

Montadert, L., Roberts, D. G., de Charpal, O., and Guennoc, P., 1979. Rifting and subsidence of the northern continental margin of the Bay of Biscay. In Montadert, L., Roberts, D. G., et al., Init. Repts. DSDP, 48: Washington (U.S. Govt. Printing Office), $1025-1060$

Moore, T. C., van Andel, T. H., Sancetta, C., and Pisias, N. G., 1978. Cenozoic hiatuses in pelagic sediments. Micropaleontology, 24: 113-138.

Naylor, D., and Mounteney, S. N., 1975. Geology of the Northwest European Continental Shelf, (Vol. 1): London (Graham, Trotman and Dudley).

Naylor, D., and Shannon, P. H., 1982. The Geology of Offshore Ireland and West Britain: London (Graham and Trotman).

Parsons, B., and Sclater, J. G., 1977. An analysis of the variation of ocean floor bathymetry and heat flow with age. J. Geophys. Res., $82: 803-827$.

Pastouret, L., and Auffret, G. A., 1976. Observations sur le microfacies des roches sédimentaires prélevées sur la marge armoricaine. Rec. Trav. Cen. Oceanol. Bretagne, 5:365-382.

Pastouret, L., Auffret, G. A., Auzende, J. M., Beuzart, P., Dubois, P., et al., 1981. La marge continentale, armoricaine, résultats d'observations en submersible et de dragages dans le canyon Shamrock. Compt. Rend. Acad. Sci. Paris, 292:741-748.

Pastouret, L., Masse, J. P., Auffret, J. P., and Auffret, G. A., 1974. Sur la présence d'Aptien inférieur à facies urgonien sur la marge continental armoricaine: conséquences paléogéographiques. Rec. Trav. Cen. Oceanol. Bretagne, 3:207-207

Pautot, G., Renard, V., de Charpal, O., Auffret, G. A., and Pastouret, L., 1976. A granite cliff deep on the North Atlantic. $\mathrm{Na}$ ture, 263:669-672.

(Ed.), in press. Geologic Evolution of the United States Atlantic Margin: Stroudsburg, PA (Van Nostrand Reinhold).

Poag, C. W., and Schlee, J. S., 1984. Depositional sequences and stratigraphic gaps on submerged United States Atlantic Margin. In Schlee, J. S. (Ed.), Interregional Unconformities and Hydrocarbon Accumulation. Mem. Am. Assoc. Petrol. Geol., 36.

Riggs, S. R., 1984. Paleoceanographic model of Neogene phosphorite deposition, U.S. Atlantic continental margin. Science, 233:123-131.

Roberts, D. G., 1975. Marine geology of the Rockall Plateau and Trough. Philos. Trans, R. Soc, London, Ser. A, 278:447-509.

Roberts, D. G., and Jones, M. T., 1975. Magnetic anomalies in the northeast Atlantic, Sheets 1 and 2. European Geol. Soc. Mtg. Abstr.

Roberts, D. G., Masson, D. G., Montadert, L., and de Charpal, O., 1981. Continental margin from the Porcupine Seabight to the Armorican marginal basin. Proc. Conf. Petrol. Geol. Cont. Shelf Northwest Europe, pp. 455-473.

Roberts, D. G., and Montadert, L., 1979. Evolution of passive rifted margins-perspective and retrospective of DSDP Leg 48. In Montadert, L., Roberts, D. G., et al., Init. Repts. DSDP, 48: Washington (U.S. Govt. Printing Office), 1143-1153.

Robinson, K. W., Shannon, P. M., and Young, D. G. D., 1981. The Fastnet Basin: an integrated analysis. Proc. Conf. Petrol. Geol. Cont. Shelf Northwestern Europe, pp. 444-454.

Rona, P. A., 1973. Worldwide unconformities in marine sediments related to eustatic changes of sea level. Nature Phys. Sci., 244:25-26.

Ruddiman, W. F., 1972. Sediment redistribution on the Reykjanes Ridge: seismic evidence. Geol. Soc. Am. Bull., 83:2039-2062.

Savin, S. M., Douglas, R. G., and Stehli, F. G., 1975. Tertiary marine paleotemperatures. Geol. Soc. Am. Bull., 86:1499-1510.
Schnitker, D., 1979. Cenozoic deep water benthic foraminifers, Bay of Biscay. In Montadert, L., Roberts, D. G., et al., Init. Repts. DSDP, 48: Washington (U.S. Govt. Printing Office), 377-389.

Schuepbach, M. A., and Vail, P. R., 1980. Evolution of outer highs on divergent continental margins. Continental Tectonics: Washington (Nat'l Acad. Sci.), pp. 50-61.

Schwarzacher, W., and Fischer, A. G., 1982. Limestone-shale bedding and perturbations of the earth's orbit. In Einsele, G., and Seilacher, A. (Eds.), Cyclic and Event Stratification: Berlin (Springer Verlag), pp. 72-95.

Scrutton, R. A., 1979. Structure of the crust and upper mantle at Goban Spur, southwest of the British Isles-some implications for margin studies. Tectonophysics, 59:201-215.

Shackleton, N. J., and Kennett, J. P., 1975. Paleotemperature history of the Cenozoic and the initiation of Antarctic glaciation: oxygen and carbon isotope analyses in DSDP Sites 277, 279, and 281. In Kennett, J. P., Houtz, R. E., et al., Init. Repts. DSDP, 29: Washington (U.S. Govt. Printing Office), 743-755.

Shor, A. H., and Poore, R. Z., 1979. Bottom currents and icerafting in the North Atlantic: interpretation of Neogene depositional environments of Leg 49 Cores. In Luyendyk, B. P., Cann, J. R., et al., Init. Repts. DSDP, 49: Washington (U.S. Govt. Printing Office), 859-872.

Sibuet, J. C., 1973. South Armorican shear zone and continental fit before the opening of the Bay of Biscay. Earth. Planet. Sci. Lett., 18:153-157.

Sibuet, J. C., Ryan, W. B. F., Arthur, M., Barnes, R., Blechsmidt, G., et al., 1980. Deep drilling results of Leg 47b (Galicia Bank area) in the framework of the early evolution of the North Atlantic Ocean. Philos. Trans. R. Soc. London, Ser. A, 294:51-61.

Surlyk, F., 1978. Jurassic basin evolution of east Greenland. Nature (London), 274:130-133.

Talwani, M., Mutter, J., and Eldholm, O., 1981. The initiation of opening of the Norwegian Sea. Proc. 26th Internat. Geol. Congr., Oceanol. Acta Suppl., 4:23-30.

Thiede, J., Agdestein, T., and Strand, J. E., 1980. Temporal and spatial variations of the upper Mesozoic and Cenozoic sediment flux to the deep North Atlantic Ocean. Mar. Geol., 36:M11-M19.

Thiede, J., Strand, J. E., and Agdestein, T., 1981. The distribution of major pelagic sediment components in the Mesozoic and Cenozoic North Atlantic Ocean. In Warme, J. E., Douglas, R. G., and Winterer, E. L. (Eds.), The Deep Sea Drilling Project: A Decade of Progress. Soc. Econ. Paleontol. Mineral. Spec. Publ., 32:67-90.

Tucholke, B. E., 1979. Relationships between acoustic stratigraphy and lithostratigraphy in the western North Atlantic basin. In Tucholke, B. E., Vogt, P. R., et al., Init. Repts. DSDP, 43: Washington (U.S. Govt. Printing Office), 827-846.

1981. Geologic significance of seismic reflectors in the deep western North Atlantic basin. In Warme, J. E., Douglas, R. G., and Winterer, E. L. (Eds.), The Deep Sea Drilling Project: A Decade of Progress. Soc. Econ. Paleontol. Mineral. Spec. Publ., 32: 23-37.

Tucholke, B. E., and Vogt, P. R., 1979. Western North Atlantic: sedimentary evolution and aspects of tectonic history. In Tucholke, B E., Vogt, B. E., et al., Init. Repts. DSDP, 43: Washington (U.S. Govt. Printing Office), 791-825.

Vail, P. R., and Hardenbol, J., 1979. Sea-level changes during the Tertiary. Oceanus, 22:71-79.

Vail, P. R., Mitchum, R. M., and Shipley, T. H., 1980. Unconformities of the North Atlantic. Philos. Trans. R. Soc. London, Ser. A, 294:137-155.

Vail, P. R., Mitchum, R. M., Jr., Todd, R. G., Widmier, J. M., Thompson, S. III, et al., 1977. Seismic stratigraphy and global changes of sea level. In Payton, C. E. (Ed.), Seismic Stratigraphy - Applications to Hydrocarbon Exploration: Mem. Am. Assoc. Petrol. Geol., 26:49-212.

van Andel, T. H., and Moore, T. C., 1974. Cenozoic calcium carbonate distribution and calcite compensation depth in the central equatorial Pacific. Geology, 2:87-92.

Vergnaud Grazzini, C., Pierre, C., and Létolle, R., 1978. Paleoenvironment of the northeast Atlantic during the Cenozoic: oxygen and carbon isotope analyses of DSDP Sites 398, 400A, and 401. Oceanol. Acta, 11:381-390. 
Williams, C. A., 1975. Seafloor spreading in the Bay of Biscay and its relationship to the North Atlantic. Earth Planet. Sci. Lett., 24: 440-456.

Woodruff, F., Savin, S. M., and Douglas, R. G., 1981. Miocene stable isotopic record: a detailed deep Pacific Ocean study and its paleoclimatic implications. Science, 212:665-668.

Ziegler, P. A., 1978. Northwestern Europe: tectonics and basin development. Geol. Mijnbouw, 57:589-626.
1981. Evolution of sedimentary basins in northwest Europe. In Illing, L., and Hobson, G. D. (Eds.), Petroleum Geology of the Continental Shelf of Northwest Europe: London (Inst. Petrol.), pp. 3-39.

Date of Initial Receipt: December 5, 1983

Date of Acceptance: April 3, 1984 